Article

\title{
Comparison of the MUSLE Model and Two Years of Solid Transport Measurement, in the Bouregreg Basin, and Impact on the Sedimentation in the Sidi Mohamed Ben Abdellah Reservoir, Morocco
}

\author{
Mohamed Abdellah Ezzaouini ${ }^{1,2}, * \mathbb{0}$, Gil Mahé ${ }^{3}$, Ilias Kacimi ${ }^{1}$ and Abdelaziz Zerouali ${ }^{2}$ \\ 1 Geoscience, Water and Environment Laboratory, Faculty of Sciences, Mohammed V University, \\ Avenue Ibn Batouta, Rabat 10100, Morocco; iliaskacimi@yahoo.fr \\ 2 Basin of the Bouregreg and Chaouia Agency, Benslimane BP 262, Morocco; azlso@yahoo.fr \\ 3 Laboratoire HydroSciences, Université Montpellier, IRD, 34090 Montpellier, France; gilmahe@hotmail.com \\ * Correspondence: ezzaouini70@yahoo.fr; Tel.: +212-661-110-897
}

Received: 18 May 2020; Accepted: 15 June 2020; Published: 1 July 2020

\begin{abstract}
The evaluation and quantification of solids transport in Morocco often uses the Universal Soil Loss Model (USLE) and the revised version RUSLE, which presents a calibration difficulty. In this study, we apply the MUSLE model to predict solid transport, for the first time on a large river basin in the Kingdom, calibrated by two years of solid transport measurements on four main gauging stations at the entrance of the Sidi Mohamed Ben Abdellah dam. The application of the MUSLE on the basin demonstrated relatively small differences between the measured values and those expected for the calibrated version, these differences are, for the non-calibrated version, $+5 \%$ and $+102 \%$ for the years 2016/2017 and 2017/2018 respectively, and between $-33 \%$ and $+34 \%$ for the calibrated version. Besides, the measured and modeled volumes that do not exceed $1.78 \times 10^{6} \mathrm{~m}^{3} /$ year remain well below the dam's siltation rate of $9.49 \times 10^{6} \mathrm{~m}^{3} /$ year, which means that only $18 \%$ of the dam's sediment comes from upstream. This seems very low because it is calculated from only two years. The main hypothesis that we can formulate is that the sediments of the dam most probably comes from the erosion of its banks.
\end{abstract}

Keywords: modeling; MUSLE; erosion; solid transport; dam; Bouregreg; Morocco

\section{Introduction}

Erosion is a natural phenomenon that reduces the capacity of dam reservoirs around the world. The natural erosive process is aggravated by anthropogenic activities including pastoral activity [1], deforestation [2-4], and climate change [5] with the advent of periods of heavy rainfall and increasingly frequent dry periods. This phenomenon constitutes a major challenge for water resource management at the scale of the Bouregreg basin [6,7] in northern Morocco.

The Sidi Mohamed Ben Abdellah (SMBA) dam, commissioned in 1974 and raised in 2007, is intended solely to supply drinking water to the coastal area between Rabat and Casablanca, which represents nearly eight million inhabitants. It has a relatively low silting rate compared to other dams in the Kingdom [8].However, it has lost $132 \mathrm{Mm}^{3}$ since its commissioning of which $58 \%$ of this volume was lost before rising the dam height, with this loss constituting a very significant reduction in its storage capacity. Given the magnitude of this situation, the modeling of soil losses in the basin aims at achieving the following objectives:

- $\quad$ analyzing the biophysical environment; 
- describing and evaluating the erosive processes affecting the Bouregreg Basin, and the solid transport by the main tributaries to the SMBA dam;

- and identifying the priority areas contributing to siltation, in order to better guide spatial planning actions.

Universal Soil Loss Equation (USLE) was first established in USA to model erosion in small agricultural catchment [9]. It is based on several parameters linked to climate, soil cover and properties, topography, and human activities. This equation has been modified and adapted several times. The MUSLE model includes the use of water flow rates [10]. Despite the difficulties encountered in calibrating and adapting the Universal Land Loss Model (USLE) to conditions in Morocco [11], most studies on watershed management in Morocco [12-15] and bordering Mediterranean regions, in particular in Algeria and Tunisia [15-17], continue to use USLE, and the revised version RUSLE [18-21], or an event normalized plot soil loss estimated by a modified USLE model—USLE-MM—as in Italy [22], most often for small basins of much less than $5000 \mathrm{~km}^{2}$. As USLE [23] and RUSLE [24] were developed for the rough assessment of annual land loss at the scale of small plots, their application to large areas leads to rather large errors $[25,26]$. However, their accuracy increases when coupled with hydrological models [27]. To overcome the difficulties in assessing the accuracy of using a simple erosion equation like USLE, Alewell et al. [28] recommend to strengthen and extend measurement and monitoring programs to build up validation data sets.

Thus, Williams [10] developed a modified version of the USLE (MUSLE) that takes into account the flow load at the outlet by taking into account the biophysical characteristics of the watershed. This model has already been applied to micro-watersheds [29,30] and gave very reliable results compared to measurements. Indeed, in the Sidi Sbaa basin in Morocco, the deviation of the results compared to the MUSLE model was $-4 \%$ by underestimating the solid inputs [31]. Samaras and Koutitas et al. [32] use MUSLE with SWAT to simulate the potential impact of land cover change on sediment yields to the sea in Greece, but with no observed validation data; while other authors like Fang [33] use the WaTEM/SEDEM model, which includes the RUSLE formula, to estimate erosion, but always without observations to compare. Only a few studies compare the erosion rates with the three USLE formulas. In Maghreb, only one study by Djoukbala et al. [34] compared them on the small basin of $384 \mathrm{~km}^{2}$ in the north of Algeria, with erosion rates quite similar between the three methods, but they were slightly superior in the case MUSLE. Unfortunately, they could not compare their results with observation data, which does not allow an assessment of the validity of the erosion rates produced in regard to real natural processes.

\section{Materials and Methods}

\subsection{Study Area}

The Bouregreg Basin, located in central western Morocco, covers a total area of approximately $10,130 \mathrm{~km}^{2}$ at its mouth in the north of the city of Rabat (Figure 1). The main rivers of the basin are the Bouregreg, the Grou, and the Korifla and its tributary, the Machraa. 


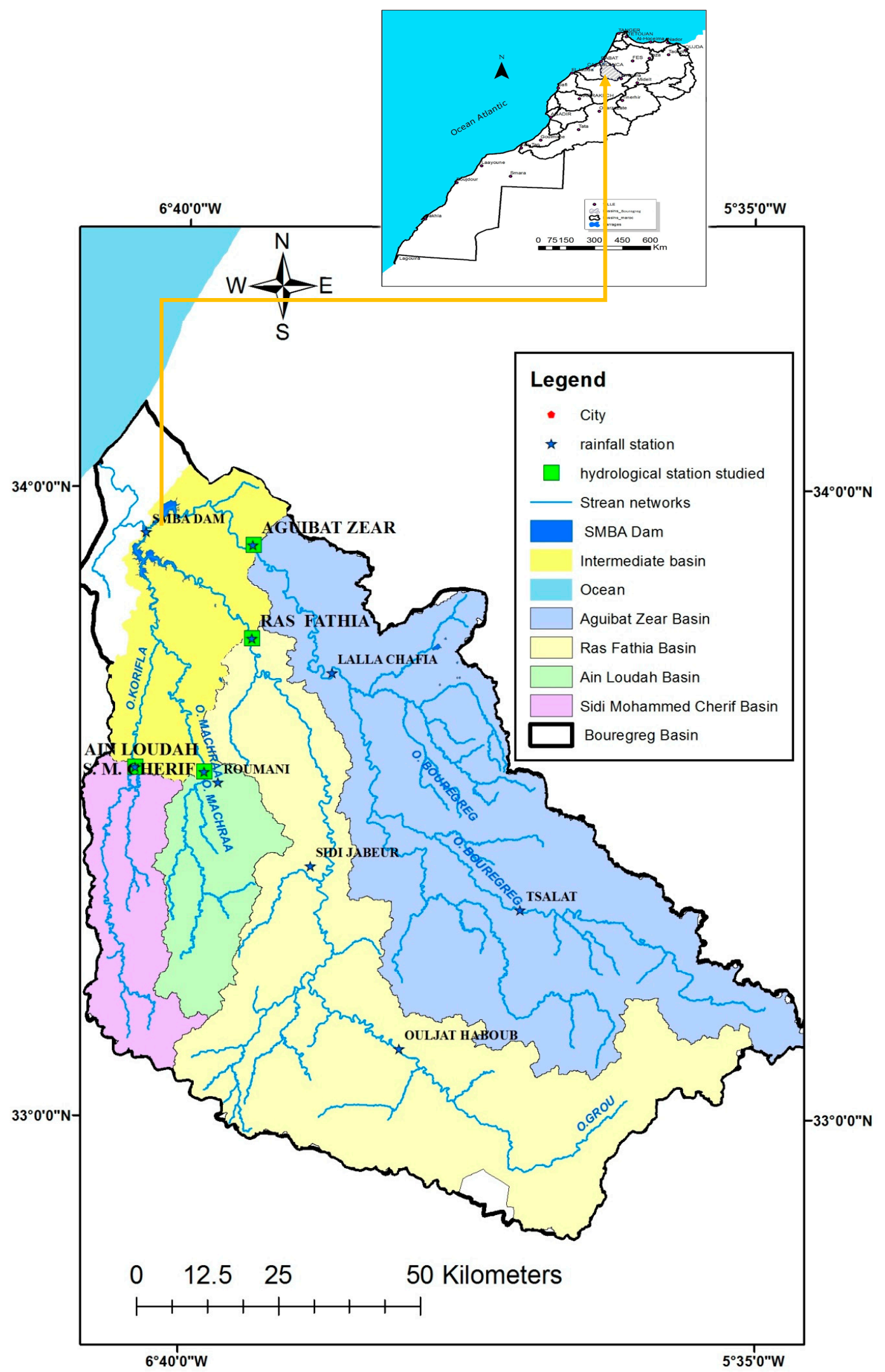

Figure 1. Situation of the Bouregreg Basin on the north Morocco Atlantic coast. 
The climate in the study area is Mediterranean with oceanic influence, with an average annual rainfall over the basin varying from $450 \mathrm{~mm}$ in Rabat in the north-west, to nearly $750 \mathrm{~mm}$ in the mountainous area in the south-east.

Rain events generate water volume of $680 \times 10^{6} \mathrm{~m}^{3} /$ year, i.e., an annual mean of $22 \mathrm{~m}^{3} / \mathrm{s}$. It is regulated by the capacity of the SMBA dam, located downstream of the confluence between the Bouregreg, Korifla/Machraa, and Grou rivers. Table 1 summarizes the characteristics of the SMBA dam.

Table 1. Sidi Mohamed Ben Abdellah (SMBA)dam data.

\begin{tabular}{|c|c|c|c|c|c|}
\hline & $\begin{array}{c}\text { Watershed } \\
\text { Area } \\
\left(\mathbf{k m}^{2}\right)\end{array}$ & $\begin{array}{c}\text { Initial Dam } \\
\text { Capacity }\left(10^{6} \mathrm{~m}^{3}\right)\end{array}$ & $\begin{array}{c}\text { Inter-Annual } \\
\text { Water Resources } \\
\quad\left(10^{6} \mathrm{~m}^{3}\right)\end{array}$ & Opening Date & $\begin{array}{c}\text { Number of } \\
\text { Bathymetric } \\
\text { Measurements }\end{array}$ \\
\hline $\begin{array}{l}\text { SMBA at its } \\
\text { construction }\end{array}$ & 9800 & 508.6 & 680 & 1974 & 5 \\
\hline $\begin{array}{l}\text { SMBA after } \\
\text { raising its dike }\end{array}$ & & 974.0 & & 2007 & 3 \\
\hline
\end{tabular}

\subsection{Basic Data}

\subsubsection{Discharges Measurements}

The hydrometric network of the Bouregreg basin upstream of the SMBA dam is composed of three major tributaries: Bouregreg, Grou, and Korifla (including its tributary the Machraa). Four hydrological stations located on these tributaries at the entrance of the dam's reservoir were chosen to carry out the measurements of solid transport. These hydrological stations control a basin of about $8521 \mathrm{~km}^{2}$, i.e., $87 \%$ of the catchment area of the SMBA dam. They also have human and material means to ensure the measurement of flows, rainfall, and the concentration of suspended solids. Table 2 gives the characteristics of the four hydrological stations.

Table 2. Characteristics of the four hydrological stations studied.

\begin{tabular}{|c|c|c|c|c|c|c|c|c|}
\hline \multirow{2}{*}{$\begin{array}{l}\text { Hydrological } \\
\text { Station }\end{array}$} & \multirow{2}{*}{$\begin{array}{l}\text { Name of } \\
\text { River }\end{array}$} & \multirow{2}{*}{$\begin{array}{c}\text { Date of } \\
\text { Commissioning }\end{array}$} & \multirow{2}{*}{$\begin{array}{l}\text { Averaging } \\
\text { Period }\end{array}$} & \multirow{2}{*}{$\begin{array}{c}\mathrm{N}^{\circ} \text { IRE } \\
\text { ABHBC } \\
\text { Code }\end{array}$} & \multirow{2}{*}{$\begin{array}{c}\text { Watershed } \\
\text { Area } \\
\left(\mathrm{km}^{2}\right)\end{array}$} & \multicolumn{3}{|c|}{ Lambert Coordinates } \\
\hline & & & & & & $x$ & $\mathbf{Y}$ & $\mathbf{Z}$ \\
\hline Aguibat Zear & Bouregreg & 1975 & $1975 / 2018$ & $3118 / 13$ & 3681 & 394.500 & 368.150 & 90 \\
\hline Ras Fathia & Grou & 1975 & $1975 / 2018$ & $989 / 20$ & 3485 & 394.250 & 351.800 & 100 \\
\hline $\begin{array}{l}\text { Ain Loudah } \\
\text { Sidi }\end{array}$ & Korifla & 1971 & $1971 / 2018$ & $2673 / 20$ & 699 & 373.750 & 329.150 & 175 \\
\hline $\begin{array}{l}\text { Mohamed } \\
\text { Cherif }\end{array}$ & Machraa & 1971 & $1971 / 2018$ & $2674 / 21$ & 656 & 385.850 & 328.200 & 270 \\
\hline
\end{tabular}

Figure 2 shows that the two years, 2016/2017 and 2017/2018, are dry years which did not record significant water inflows.

Examination of the historical measurement data from the four observation stations shows that $80 \%$ of the inflows to the dam are recorded between October and May (Figure 3). The Bouregreg and Grou rivers contribute more than $90 \%$ of the inflows generated in the basin.

Table 3 shows the maximum flows, volumes, and number of flood events recorded during the 2016/2017 and 2017/2018 hydrological years at the four hydrological stations studied. The number of recorded events is between six and seventeen, depending on the observation station and the year. 


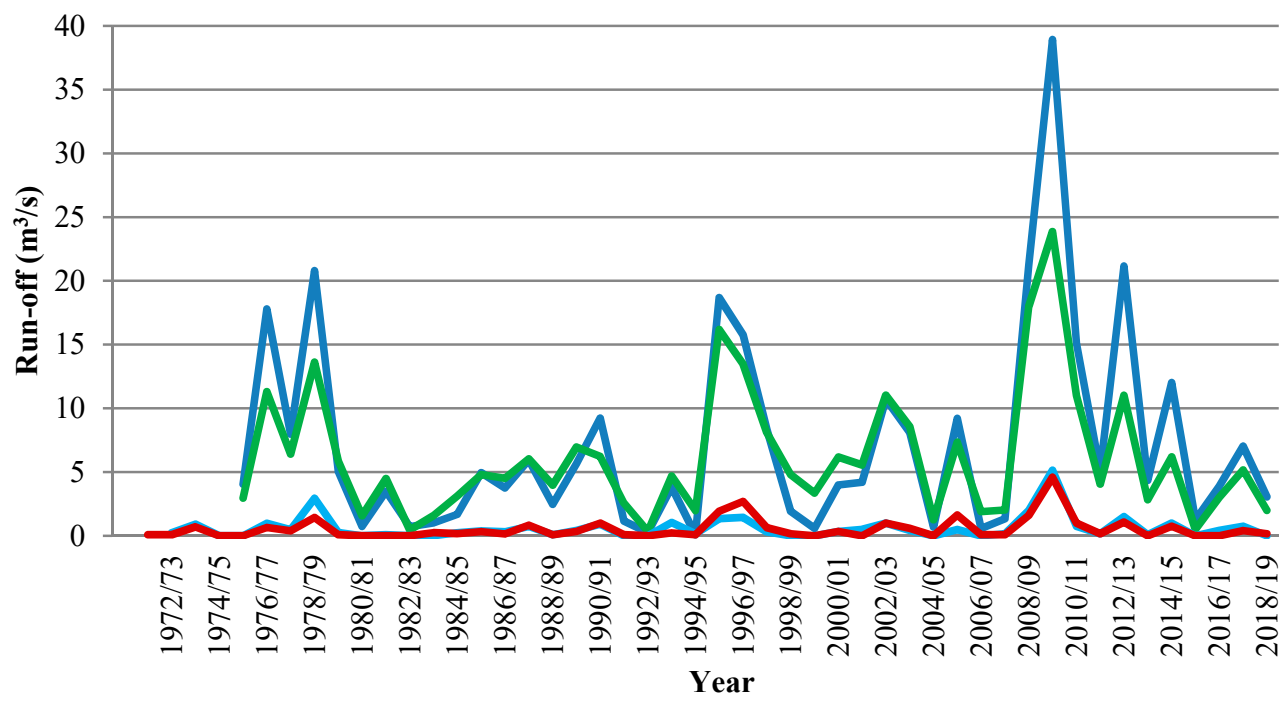

$\longrightarrow$ Aguibat Zear $\longrightarrow$ Ras Fathia $\longrightarrow$ Ain Loudah $\longrightarrow$ Sidi Mohamed Cherif

Figure 2. Annual discharges at the 4 hydrological stations studied.

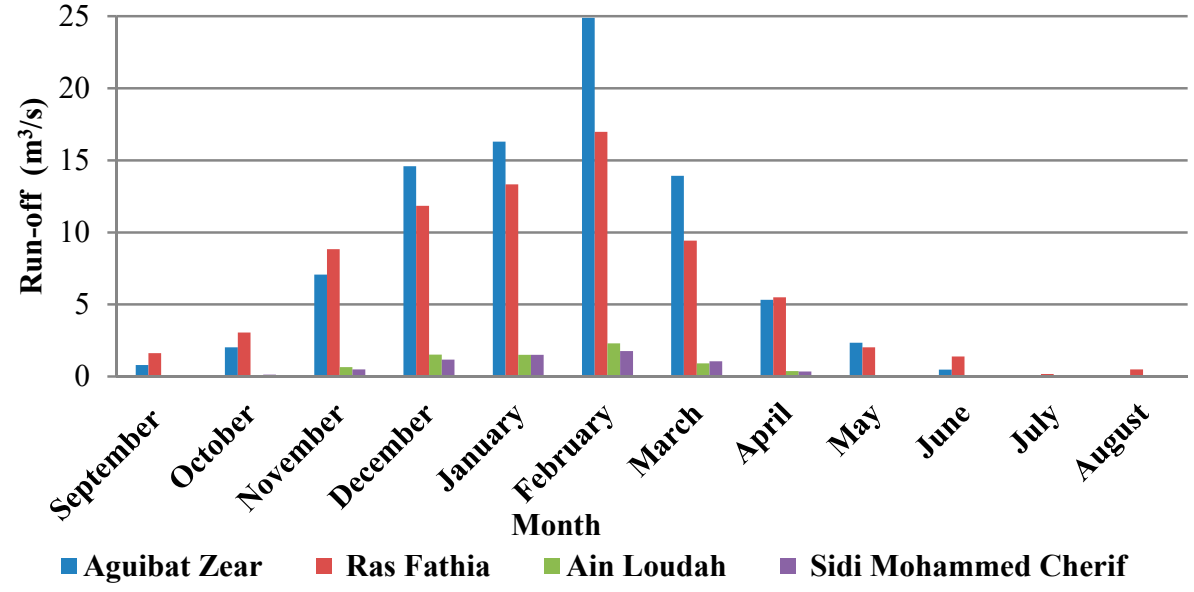

Figure 3. Mean monthly discharges at the hydrological stations studied.

Table 3. Flood events for the four hydrological stations studied.

\begin{tabular}{|c|c|c|c|c|c|}
\hline $\begin{array}{l}\text { Hydrological } \\
\text { Station }\end{array}$ & $\begin{array}{c}\text { Hydrological } \\
\text { Year }\end{array}$ & $\begin{array}{c}\text { Maximum } \\
\text { Discharge } \\
\text { Recorded Per Year } \\
\left(\mathrm{m}^{3} / \mathrm{s}\right)\end{array}$ & Date of Flood Event & $\begin{array}{l}\text { Volume } \\
\left(10^{6} \mathrm{~m}^{3}\right)\end{array}$ & $\begin{array}{l}\text { Number of } \\
\text { Flood Events }\end{array}$ \\
\hline \multirow{2}{*}{ Aguibat Zear } & $2016 / 2017$ & 263.4 & $24 / 02 / 2017$ at $23 \mathrm{~h} 00$ & 52 & 13 \\
\hline & $2017 / 2018$ & 265.9 & $07 / 03 / 2018$ at $14 \mathrm{~h} 00$ & 77 & 14 \\
\hline \multirow{2}{*}{ Ras Fathia } & $2016 / 2017$ & 256.4 & $25 / 02 / 2017$ at $07 \mathrm{~h} 30$ & 33 & 11 \\
\hline & $2017 / 2018$ & 423.8 & $07 / 03 / 2018$ at $09 \mathrm{~h} 00$ & 59 & 10 \\
\hline \multirow{2}{*}{ Ain Loudah } & $2016 / 2017$ & 24.5 & $13 / 10 / 2016$ at $11 \mathrm{~h} 00$ & 0.7 & 10 \\
\hline & $2017 / 2018$ & 198.7 & $24 / 04 / 2018$ at $23 \mathrm{~h} 00$ & 7.6 & 17 \\
\hline \multirow{2}{*}{$\begin{array}{l}\text { Sidi Mohamed } \\
\text { Cherif }\end{array}$} & $2016 / 2017$ & 62.6 & $13 / 10 / 2016$ at $07 \mathrm{~h} 00$ & 1.8 & 6 \\
\hline & $2017 / 2018$ & 48.0 & $11 / 12 / 2017$ at $17 \mathrm{~h} 00$ & 1.28 & 6 \\
\hline
\end{tabular}

\subsubsection{Concentration of Suspended Solids (CSS)}

Observers at the four hydrological stations studied, who are contracted by the Hydraulic Basin of the Bouregreg and Chaouia Agency (ABHBC), carry out daily sampling during low-flow periods and hourly sampling during periods of flooding. At each instantaneous sampling, the date, time, and scale 
rating are noted on the specimen bottles catalogued. The samples are then analyzed in the laboratory and filtered under a vacuum using filtering membranes $(0.45 \mu \mathrm{m})$. The available data for measuring the concentration of suspended solids cover two hydrological years, 2016/2017 and 2017/2018. The number of measurement samples is presented in Table 4.

Table 4. Number of concentration of suspended solids (CSS)samples and floods events per station.

\begin{tabular}{ccccc}
\hline $\begin{array}{c}\text { Name of Hydrological } \\
\text { Station }\end{array}$ & River & $\begin{array}{c}\text { Watershed } \\
\left.\text { Area } \mathbf{( k m}^{2}\right)\end{array}$ & $\begin{array}{c}\mathbf{2 0 1 6 / 2 0 1 7} \text { and 2016/2018 } \\
\text { Number of CSS } \\
\text { Samples }\end{array}$ & $\begin{array}{c}\text { Number of Flood } \\
\text { Events }\end{array}$ \\
\hline AguibatZear & Bouregreg & 3681 & 727 & 27 \\
Ras Fathia & Grou & 3485 & 636 & 21 \\
Ain Loudah & Korifla & 699 & 233 & 27 \\
Sidi Mohamed Cherif & Machraa & 656 & 789 & 12 \\
\hline
\end{tabular}

\subsubsection{Bathymetric Data}

In order to draw up an inventory of the silting of the SMBA dam reservoir, the bathymetric surveys carried out by the Moroccan Directorate of Water Research and Planning were collected and analyzed. A total of seven bathymetric surveys were collected, the oldest dating back to 1974, while the most recent were carried out in 2013. Analysis of the bathymetric data shows that the silting up of the SMBA dam reservoir was of the order of $2.65 \times 10^{6} \mathrm{~m}^{3} /$ year, i.e., a specific degradation of $270.4 \mathrm{~m}^{3} / \mathrm{km}^{2} /$ year before raising. After raising, the silting increased to $9.49 \times 10^{6} \mathrm{~m}^{3} /$ year, i.e. a specific degradation of $968.37 \mathrm{~m}^{3} / \mathrm{km}^{2} /$ year, which increased the silting rate by $400 \%$ [4]. However, the data is subject to doubt for values in the early 2000s [35].The difference between the beginning and the end of the chronicle is of reliable quality. Therefore, the total silting of the SMBA dam reached $132 \times 10^{6} \mathrm{~m}^{3}$, i.e., an average silting rate of $3.7 \times 10^{6} \mathrm{~m}^{3} /$ year since its commissioning. Subsequently, the dam has exceeded its dead unit, which is sized for $100 \times 10^{6} \mathrm{~m}^{3}$ and has lost $32 \times 10^{6} \mathrm{~m}^{3}$ of its useful reserve since its commissioning. Table 5 summarizes the silting status of the dam.

Table 5. Summary of SMBA dam siltation calculation results since its impoundment.

\begin{tabular}{|c|c|c|c|c|c|c|c|}
\hline $\begin{array}{l}\text { Name of the } \\
\text { Dam }\end{array}$ & $\begin{array}{c}\text { Initial Dam } \\
\text { Capacity } \\
\left(10^{6} \mathrm{~m}^{3}\right)\end{array}$ & $\begin{array}{c}\text { Total } \\
\text { Siltation } \\
\left(10^{6} \mathrm{~m}^{3}\right)\end{array}$ & $\begin{array}{l}\text { Number } \\
\text { of Years }\end{array}$ & $\begin{array}{c}\text { Rate of } \\
\text { Siltation } \\
\left(10^{6} \mathrm{~m}^{3}\right)\end{array}$ & $\begin{array}{c}\text { Dead-unit } \\
\text { Volume at } \\
\text { Dam } \\
\text { Building } \\
\left(10^{6} \mathrm{~m}^{3}\right)\end{array}$ & $\begin{array}{c}\text { Lost } \\
\text { Volume } \\
(\%)\end{array}$ & $\begin{array}{l}\text { Current } \\
\text { Capacity } \\
\left(10^{6} \mathrm{~m}^{3}\right)\end{array}$ \\
\hline $\begin{array}{l}\text { SMBA before } \\
\text { raising }\end{array}$ & 508.60 & 76.88 & 29 & 2.65 & 100.00 & 15 & 431.72 \\
\hline
\end{tabular}

The silting of the dam reservoir represents a real threat to the sustainability of the mobilization of surface water resources in the Bouregreg basin to satisfy required needs. The regulation of the SMBA dam, prior to its raising, was done on a seasonal basis (capacity lower than the annual inflow). In other words, the dam had to discharge the surplus inflows most often from flood spillway or bottom discharge. This technique of management favored the elimination of solid deposits and thus a reduction in the siltation rate of the dam. After the dam was raised and consequently the water capacity of the reservoir increased, the SMBA dam moved to multi-year regulation (capacity greater than annual inflows). By using the restitution devices of the dam, this method of regulation favors storage to the detriment of evacuation, which accentuates the silting rate. Figure 4 illustrates the evolution over time of the normal capacity of the SMBA dam. 


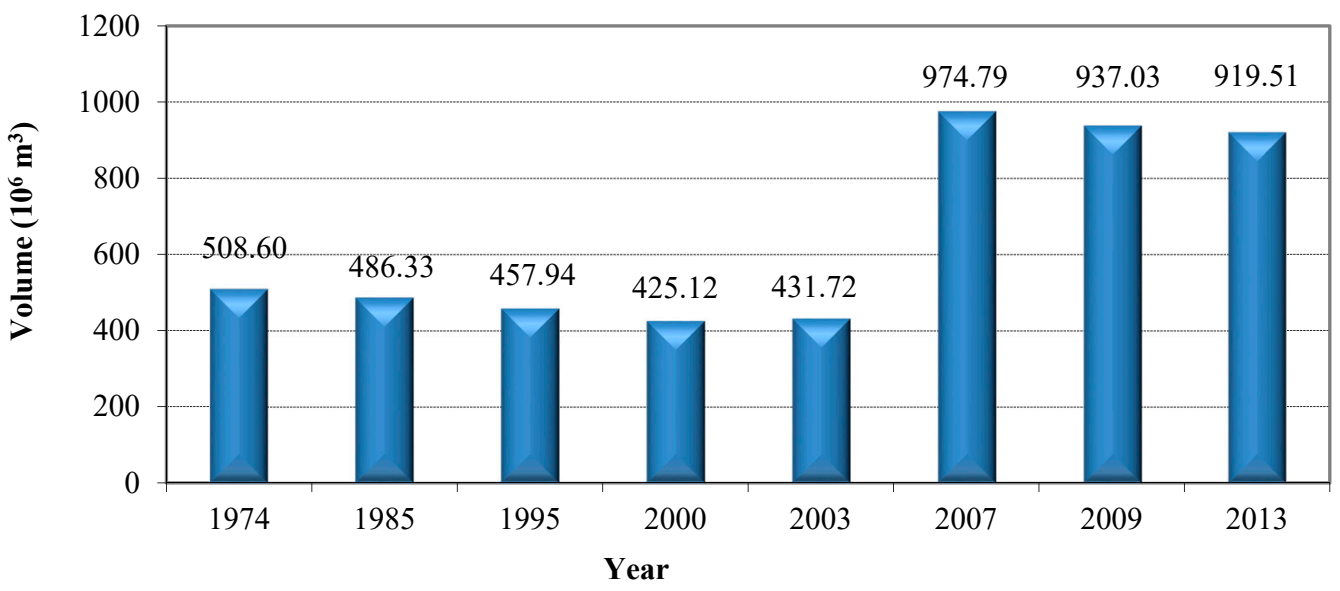

Figure 4. Evolution of the normal capacity of the SMBA dam reservoir, in millions of $\mathrm{m}^{3}$.

\subsection{Methods}

\subsubsection{Model Selection}

In this study we apply the Williams [10] model based on the Modified Universal Soil Loss Equation (MUSLE), integrated in the ArcGIS Geographic Information System for the determination of the soil loss potential at the level of the Bouregreg watershed to the four hydrological stations located immediately upstream of the SMBA dam, as previously done by Khali Issa et al. [36] in another region of Morocco in the North of the country, over a very small basin of $38 \mathrm{~km}^{2}$.

This model evaluates the average annual rate of erosion at the outlet of the basin. It uses hydrological parameters, measured at the four hydrological stations, taking into account biophysical characteristics. Thus, the model equation is as follows:

$$
A=a\left(Q_{\max } \times V_{t}\right)^{b} K \times L S \times C \times P,
$$

where $A$ : amount of sediment produced at the outlet in tons, a and $\mathrm{b}$ : in this study, we used the scale factor values of the Sidi Sbaa micro-basin [30] $(a=11.8$ and $b=0.56), Q_{\max }$ : maximum flow rate in $\mathrm{m}^{3} / \mathrm{s}, V_{t}$ : total volume of runoff water in $\mathrm{m}^{3}, K$ : average soil erodibility (mg MJ-1mm-1), LS: average topographic factor, $C$ : average vegetation cover factor, $P$ : average cultural practices and amenities factor.

\subsubsection{Methods Selection}

We adopted the suite of methods and operations explained in the flowchart (Figure 5) below to assess siltation rates at hydrological stations upstream of the SMBA dam [37]. 


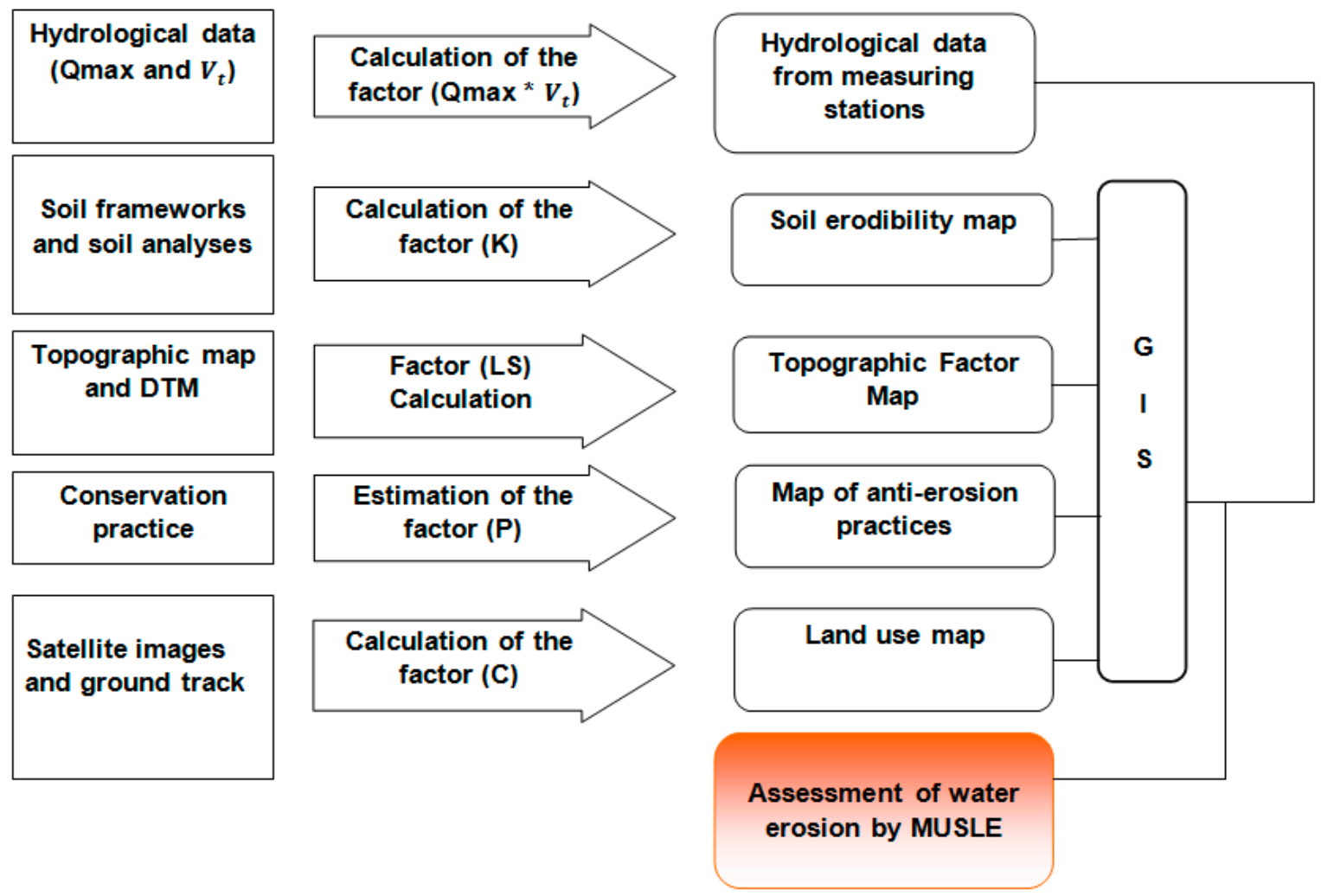

Figure 5. Methodology adopted for the assessment of erosion in the Bouregreg basin.

\section{Results}

\subsection{Rainfall and Hydrometric Analysis}

Solid transports are calculated at the four hydrological stations concerned in the hydrological years 2016/2017 and 2017/2018. These two years were respectively dry and wet in terms of rainfall. The average rainfall recorded at all the rainfall stations in the basin reached $354 \mathrm{~mm}$ in 2016/2017 and $496 \mathrm{~mm}$ in 2017/2018. Thus, the rainfall differences recorded in relation to the arithmetic mean of the data from the rainfall stations located in the Bouregreg basin varied respectively by $-10 \%$ and $+26 \%$ since the commissioning dates of the stations, based on data available to study from the ABHBC.

Table 6 summarizes the rainfall variations recorded in relation to the average rainfall of the stations in the Bouregreg basin.

Table 6. Rainfall for the 2016/2017 and 2017/2018 water years.

\begin{tabular}{|c|c|c|c|c|c|c|c|}
\hline \multirow[t]{2}{*}{$\begin{array}{l}\text { Rain Gauge } \\
\text { Station }\end{array}$} & \multirow[t]{2}{*}{ Basin } & \multicolumn{2}{|c|}{$\begin{array}{l}\text { Cumulative Rainfall } \\
\text { (mm) }\end{array}$} & \multirow[t]{2}{*}{$\begin{array}{l}\text { Averaging } \\
\text { Period }\end{array}$} & \multirow[t]{2}{*}{$\begin{array}{l}\text { Mean } \\
\text { Year } \\
(\mathrm{mm})\end{array}$} & \multicolumn{2}{|c|}{$\begin{array}{c}\text { Deviation } \\
\text { from the Mean } \\
(\%)\end{array}$} \\
\hline & & $2016 / 2017$ & $2017 / 2018$ & & & $2016 / 2017$ & $2017 / 2018$ \\
\hline LallaChafia & Bouregreg & 409 & 569 & $1972 / 2019$ & 486 & -16 & 17 \\
\hline AguibatZear & Bouregreg & 482 & 578 & $1975 / 2019$ & 429 & 12 & 35 \\
\hline Sidi Jabeur & Grou & 260 & 432 & $1971 / 2019$ & 317 & -18 & 36 \\
\hline Tsalat & Bouregreg & 454 & 622 & $1977 / 2019$ & 469 & -3 & 33 \\
\hline Roumani & Machraa & 261 & 431 & $1933 / 2019$ & 342 & -24 & 26 \\
\hline Ras Fathia & Grou & 290 & 505 & $1975 / 2019$ & 387 & -25 & 30 \\
\hline S. M Cherif & Machraa & 290 & 495 & $1971 / 2019$ & 367 & -21 & 35 \\
\hline Barrage SMBA & Bouregreg & 518 & 479 & $1984 / 2019$ & 469 & 10 & 2 \\
\hline OuljatHaboub & Grou & 321 & 350 & $1972 / 2019$ & 311 & 3 & 12 \\
\hline Ain Loudah & Krofla & 258 & 498 & $1971 / 2019$ & 347 & -26 & 43 \\
\hline Total & & 354 & 496 & & 392 & -10 & 26 \\
\hline
\end{tabular}


With the exception of the Korifla sub-basin at the right of the Ain Loudah station which recorded a surplus of nearly $24 \%$ during 2017/2018, the contributions were in deficit on the rest of the sub-basins during the two hydrological years with more pronounced deficits during the dry year 2016/2017. Table 7 summarizes the inflows recorded at the four stations of the study.

Table 7. Water supplies to the four hydrological stations studied.

\begin{tabular}{ccccccccc}
\hline $\begin{array}{c}\text { Hydrological } \\
\text { Station }\end{array}$ & River & \multicolumn{3}{c}{ Water Supply $\mathbf{( M m}^{\mathbf{3}}$ ) } & & \multicolumn{2}{c}{$\begin{array}{c}\text { Deviation } \\
\text { from the Mean (\%) }\end{array}$} \\
& & $\mathbf{2 0 1 6 / 2 0 1 7}$ & $\mathbf{2 0 1 7 / 2 0 1 8}$ & $\begin{array}{c}\text { Averaging } \\
\text { Period }\end{array}$ & $\begin{array}{c}\text { Annual } \\
\text { Average } \\
\text { (mm) }\end{array}$ & $\mathbf{2 0 1 6 / 2 0 1 7}$ & $\mathbf{2 0 1 7 / 2 0 1 8}$ \\
\hline AguibatZear & Bouregreg & 122.2 & 221.5 & $1975 / 2019$ & 227.6 & -46 & -3 \\
$\quad$ Ras Fathia & Grou & 95.0 & 162.8 & $1975 / 2019$ & 194.2 & -51 & -16 \\
Ain Loudah & Korifla & 13.3 & 23.5 & $1971 / 2019$ & 18.9 & -29 & +24 \\
$\quad \begin{array}{c}\text { Sidi } \\
\text { Mohammed } \\
\text { Cherif }\end{array}$ & Machraa & 3.7 & 12.9 & $1971 / 2019$ & 16.7 & -77 & -23 \\
\hline
\end{tabular}

\subsection{Analysis of the Biophysical Environment}

The analysis of the biophysical environment consists of determining the average factors used by the model for each sub-basin. These factors, that affect soil erosion, are: soil type, topography, land use and cropping practices, and erosion control facilities [38].

\subsubsection{Soil Erodibility Factor (K)}

Erodibility is defined as the degree to which soils are resistant to erosion. The factors that have a major influence on the response of soils to erosion, namely the detachment and transport of particles by rain and runoff, are texture, structure, organic matter, and permeability. The methodology for estimating RUSLE K has been applied, and is written as follows [39]:

$$
\mathrm{K}=\left[2.1 \times 10^{-4}(12-\mathrm{MO}) \mathrm{M}^{1.14}+3.25(\mathrm{~S}-2)+2.5(\mathrm{P}-3)\right] / 10,
$$

with K: soil erodibility expressed in t.ha.h/ha.MJ.mm (tonne. hectare. hour/hectare. mega joule. millimeter); MO: percentage of organic matter; M: textural term \% fine sand + \% silt; S: structure class code 1 to 4 , with 1 fragmented structure and 4 coarse structure, soil structure affects both landslide susceptibility and infiltration, the profiles described on the Bouregreg have a subangular polyhedral structure and fall under class (3); and P: the permeability code (1 to 6), its value can be inferred indirectly from the organic matter content by calculating the infiltration given by the Equation [40]:

$$
\mathrm{Y}=3.53 \times \mathrm{X}+2.08
$$

with: $\mathrm{Y}=$ infiltration in $\mathrm{cm} / \mathrm{h}, \mathrm{X}=$ organic matter in $\%$.

Thereafter, the soil erodibility factor $\mathrm{K}$ will be calculated using the Harmonized World Soil Database (HWSD), developed by the Food and Agriculture Organization of the United Nations (FAO) (http://www.fao.org/soils-portal/fr/). This database gives the distribution of silt, sand, and clay soil compositions by soil type [41].

Soil is composed of organic and mineral matter. Its texture is determined by the size of the soil particles and their respective quantities. There are three categories of particles that determine soil texture: sand, silt, and clay. They are distinguished by particle diameter: sand $0.05 \mathrm{~mm}$ to $2 \mathrm{~mm}$, silt $0.002 \mathrm{~mm}$ to $0.05 \mathrm{~mm}$, clay $0.002 \mathrm{~mm}$ and less. The modified illustrated triangular graph [42] was used to determine soil texture classification.Soil texture is classified according to the percentage of silt, sand, and clay. 
Once the textures have been determined, it is possible to establish the correspondence between the standard texture and the K-factor [43]. These values are given in tons/ha and ton/acre (US system). Although this methodology provides an approximation in the calculation of the K-factor, it has the advantage of lending itself to the constraints imposed by the study area. The rate of organic matter at the level of each watershed for each texture value is calculated by converting organic carbon into organic matter. The conversion factor of 1.724 is commonly used to convert the organic carbon content of a soil sample to organic matter. The conversion factor is old and has survived the test of time and modern analytical methods. According to authors [44], this conventional factor is attributed to the 19th century authors Van Bemmelen [45], Wolff [46], or even Sprengel [47]. It is based on well-established and very old studies showing that soil organic matter contains $58 \%$ carbon. Since the C/MO ratio would be equal to 0.58 , the $\mathrm{MO} / \mathrm{C}$ ratio would be equal to 1.724 .

Thus, the calculation of the organic matter is carried out by the following formula, which uses the value 1.724 and is widely used in Morocco:

$$
\mathrm{MO}=\mathrm{CO} \times 1.724
$$

the average erodibility factor $\mathrm{K}$ per basin is calculated by the formula:

$$
\mathrm{K}_{\mathrm{average}}=\frac{\sum(\mathrm{K} \times \text { number })}{\sum \text { number }},
$$

with K: K-factor per value, number: counting of pixels with the same K-value in the Arcmap allocation table.

The results of the calculation of the average K-factor for each watershed are in Table 8.

Table 8. Average erodibility factor for each watershed.

\begin{tabular}{cc}
\hline Name Watershed & Erodibility Factor $\mathbf{K}_{\text {average }}$ \\
\hline Bouregreg & 0.352 \\
Grou & 0.350 \\
Ain Loudah & 0.348 \\
Sidi Mohamed Cherif & 0.348 \\
\hline
\end{tabular}

The Kmoy factor used is 0.35 . This value corresponds to the silt, with the latter being a sedimentary formation whose grains are of intermediate size between clays and sands. The loss of silt leads to a decrease in the water retention capacity of the soil. The result is an increased erodibility and an increased risk of erosion. Because silt is often suspended in water, it is easily transported by floods and can contribute to the siltation of dam reservoirs. Figure 6 shows the distribution of the $\mathrm{K}$ factor over the Bouregreg basin for the four hydrological stations located immediately upstream of the SMBA dam. 


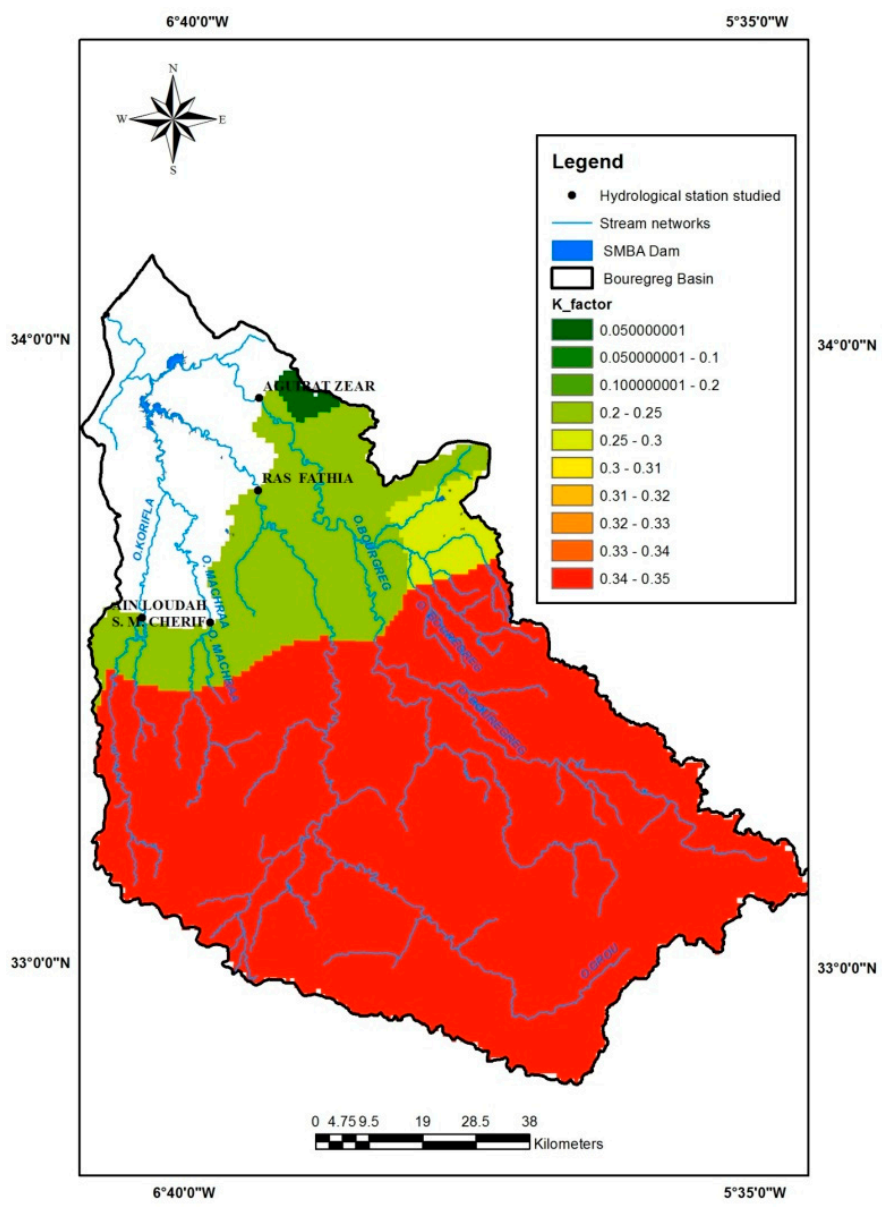

Figure 6. K-factor of the Bouregreg basin at the four hydrological stations.

\subsubsection{Topographic Factor (LS)}

The topographic factor LS is an essential parameter of the model. It expresses the result of erosion due to the combined effect of the degree of slope and its length. Most recent studies for the determination of the soil loss potential at the watershed level by the MUSLE model utilize the equation established by Wischmeier and Smith $[9,23]$, which is expressed as:

$$
L S=\left(\frac{\kappa}{22.13}\right)^{m} \times 65.4 \sin ^{2} \beta+4.56 \sin \beta+0.0654,
$$

with: $\kappa$ : length of the slope in $m$, $\beta$ : slope in degrees, $m=0.5$ if $\beta \geq 5 \%, m=0.3$ if $1<\beta<5 \%, m=0.2$ if $\beta \leq 1$.

First, the slope map was established by the spatial analyst tool of the ArcGis software using a $90 \mathrm{~m}$ resolution DTM. Then, the LS map (Figure 7) by basin was generated using the Wishmeierand Smith formula $[9,23]$. The mean slopes and mean LS values are given in Table 9.

Table 9. Mean slope and mean topographic factor (LS).

\begin{tabular}{ccc}
\hline & $\begin{array}{c}\text { Mean Slope } \\
\mathbf{( \% )}\end{array}$ & Mean Topographic Factor (Ls) \\
\hline Bouregreg à Lala Chafia & 16.6 & 0.48 \\
Grou à Ras Fathia & 14.6 & 0.49 \\
Korifla à Ain Loudah & 9.8 & 0.27 \\
Machraa à Sidi Mohamed Cherif & 12.2 & 0.58 \\
\hline
\end{tabular}




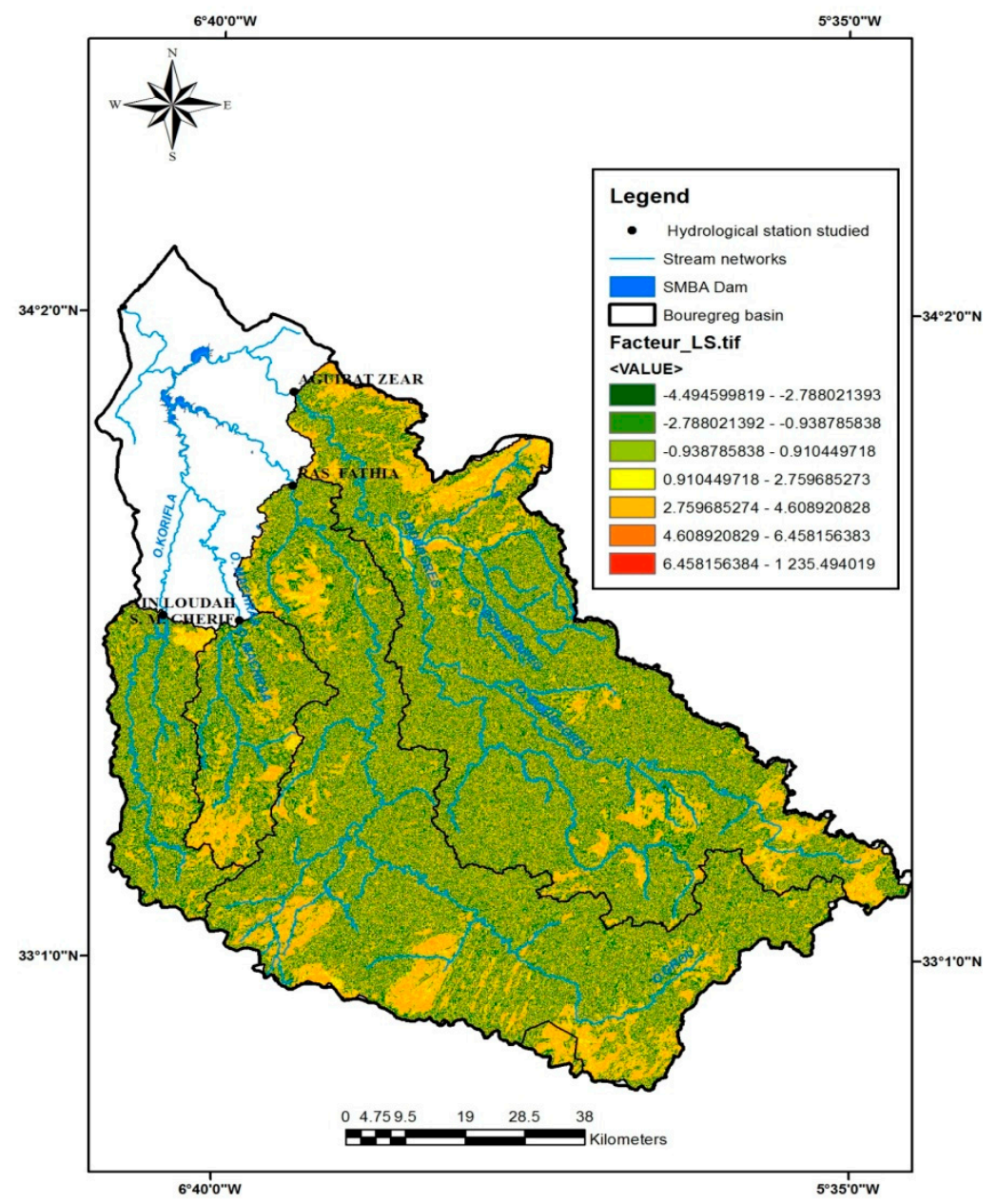

Figure 7. LS factor of the Bouregreg basin at the four hydrological stations.

\subsubsection{Land Cover Factor (C)}

The soil protection factor $(\mathrm{C})$ indicates the degree of soil protection by vegetation cover. This factor has undergone several changes since the establishment of the universal soil loss equation. The vegetation cover is-after topography-the second most important factor controlling the risk of soil erosion. The value of $C$ depends mainly on the percentage of vegetation cover and the growth phase. The $C$ factor map for the Bouregreg catchment area was derived from the land use maps. These were determined from the use of remote sensing data and field observations [48]. The land cover map was extracted from SPOT satellite images at $20 \mathrm{~m}$ resolution combined with recent Landsat ETM+ images (2011/2012) using the supervised classification method [41]. Another approach could be to derive the C factor from NDVI maps as practiced on the Wadi Mina in Algeria by Toumi et al. [16].

The distribution of surfaces according to the nature of the vegetation cover is carried out by the ArcGis tool, which subdivides the catchment area into several polygons. Each polygon corresponds to a specific type of vegetation cover. Each vegetation cover corresponds to a factor given by Wischmeir and Smith according to the theme [49]. A color is assigned to each polygon that represents a land cover type. For the calculation of the Cfactor, an independent calculation is required for each sub-basin. Indeed, the sensitivity to erosion of the different classes is determined from the main land use themes, i.e., forest formations, rangelands, agricultural land, arboriculture, water, and bare soil, whose values 
vary between 0 and 1 . The calculation of the average vegetation cover factor depends on the factor given for each land use and surface area by the following formula:

$$
\mathrm{C}_{\text {average }}=\frac{\sum \mathrm{S}_{\mathrm{i}} \cdot \mathrm{C}_{\mathrm{i}}}{\sum \mathrm{S}_{\mathrm{i}}}
$$

with $\mathrm{S}_{\mathrm{i}}$ : partial polygon area, $\mathrm{C}_{\mathrm{i}}$ : value of the $\mathrm{C}$ factor according to the theme. Figure 8 shows the $\mathrm{C}$ factors for each sub-basin of the Bouregreg River.

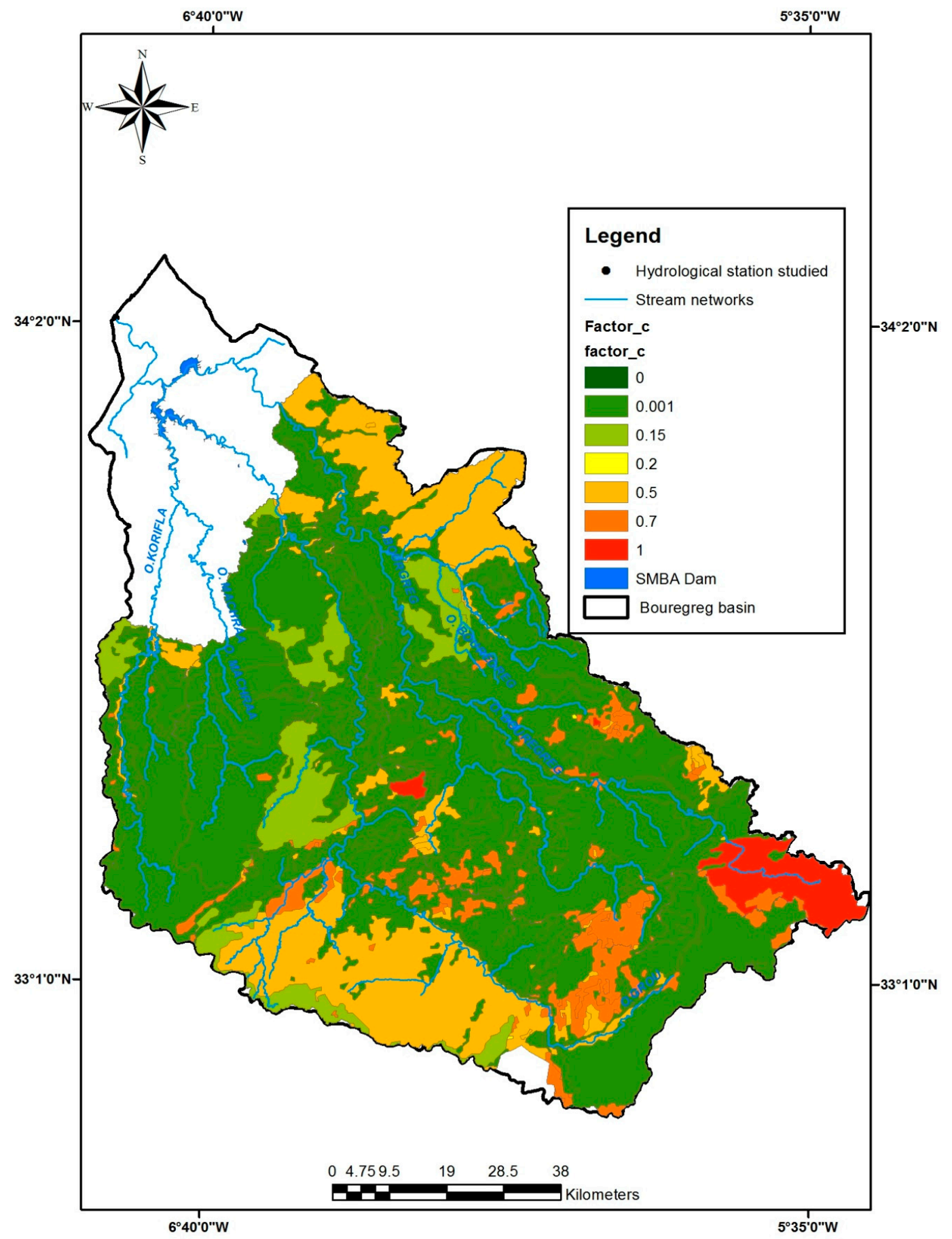

Figure 8. Factor $\mathrm{C}$ of the Bouregreg basin at the four hydrological stations.

The application of the formula leads to the results presented in Table 10. 
Table 10. Average vegetation cover factor $C$ for each watershed.

\begin{tabular}{cc}
\hline Watershed & $\begin{array}{c}\text { Land Cover Factor (C) } \\
\text { C }_{\text {average }}\end{array}$ \\
\hline Bouregreg & 0.26 \\
Grou & 0.45 \\
Korifla & 0.41 \\
Machraa & 0.33 \\
\hline
\end{tabular}

The vegetation cover factor (C) can vary from close to 0 for well-protected soils, to 1 for striated surfaces that are very sensitive to gully erosion. The determination of this factor for the Bouregreg watershed and sub-basins is based on the density of vegetation and the height of the vegetation strata. These data were deduced from the field updating of the land use map by the Royal Centre for Remote Sensing in Space of Morocco (CRTS) available at the ABHBC. The values assigned to the different land use patterns are based on Wischmeier and Smith's tables for forests, matorrals, and pastures. The results show that the values of the $C$ factor range from 0.26 for the sub-basin located in the northeast region, the Bouregreg, the wettest, to 0.45 for the sub-basin that extends furthest south, which is more arid $[50,51]$. The spatial distribution of the vegetation cover index by class for the Bouregreg watershed shows on $50.45 \%$ of the total surface area, i.e., nearly $181,556 \mathrm{ha}$, an index lower than or equal to 0.2 , indicating good protection, while $49.5 \%$ of the surface area shows very low protection against erosion, i.e., about 177,986 ha. It can also be noted that the upper northeastern basin, which is both the most humid and the least covered with vegetation, is not, however, subject to high erodibility [52].

\subsubsection{Average Cultivation Practices and Amenities Factor $P$}

The $\mathrm{P}$ factor is a dimensionless factor expressing soil protection through agricultural practices (P).This factor takes into account purely anti-erosion practices. Contour, strip or terrace cultivation, bench planting, and ridging are the most effective soil conservation practices. These practices proportionally affect erosion by altering the flow pattern or direction of surface runoff and by reducing the amount and speed of runoff. $P$ values are less than or equal to 1 . A value of 1 is assigned to lands where none of the practices listed are used. $P$ values vary between 0 and 1 depending on the practice adopted and also on the slope. In the Bouregreg watershed, there are few anti-erosion facilities and farmers do not use anti-erosion cultivation practices. These actions are small-scale and do not have a major impact on reducing erosion due to the size of the basin. As a result, a P value equal to 1 has been assigned to the entire area of the basin.

\subsection{Application and Calibration of the MUSLE Model}

\subsubsection{Application of the MUSLE Model}

The parameters required for the application of the MUSLE model for the evaluation of solid inputs by the MUSLE model are summarized in Table 11.

Table 11. Averaging factors for the universal soil loss equation modified per sub-basin.

\begin{tabular}{ccccc}
\hline & $\begin{array}{c}\text { Mean Topographic } \\
\text { Factor } \\
\text { (LS) }\end{array}$ & $\begin{array}{c}\text { Mean Erodibility } \\
\text { Factor } \\
\mathbf{( K )}\end{array}$ & $\begin{array}{c}\text { Mean Vegetation } \\
\text { Cover Factor } \\
\text { (C) }\end{array}$ & $\begin{array}{c}\text { Mean } \\
\text { Development } \\
\text { Factor (P) }\end{array}$ \\
\hline Bouregreg & 048 & 0.32 & 0.26 & 1 \\
Grou & 0.49 & 0.32 & 0.45 & 1 \\
Korifla & 0.27 & 0.34 & 0.33 & 1 \\
Machraa & 0.58 & 0.31 & 0.41 & 1 \\
\hline
\end{tabular}


By introducing the various factors of the MUSLE model, the amount of solid inputs produced at the outlet of each watershed is calculated using the flow and volume measurement data for each flood, according to the model equation. The solids transport is then calculated using the measured suspended solids concentrations for the same floods. The concentrations are linearly interpolated over the range of flows in each hydrograph. The bottom solid transport is taken as $10 \%$ of the total volume of suspended solids [53], which remains an empirical but widely used value.

\subsubsection{Calibration of the MUSLE Model}

Calibration of the model at each hydrological station is carried out using the percentage bias method (PBIAS), which consists of minimizing the difference between the observed mean and the mean predicted by the model by acting on the model's scaling parameters a and $\mathrm{b}$ :

$$
\text { PBIAS }=\left[\frac{\sum_{i=1}^{n}\left(Y_{i}^{\text {obs }}-Y_{i}^{\text {sim }}\right) \times(100)}{\sum_{i=1}^{n}\left(Y_{i}^{\text {obs }}\right)}\right],
$$

with $Y_{i}^{\text {obs: }}$ observed solid transport, $Y_{i}^{\text {sim }}$ : solid transport simulated by MUSLE, n: number of observations.

In our case, $\mathrm{a}$ and $\mathrm{b}$ are respectively equal to 11.80 and 0.56 . The calibration period is spread over two years of observations available. The optimal value of PBIAS is 0 , where PBIAS has the ability to clearly indicate poor model performance [54]. To ensure model reliability, the model is also calibrated using the KGE (Kling-Gupta Efficiency) Method [55]:

$$
\mathrm{KGE}=1-\sqrt{(r-1)^{2}+\left(\frac{\sigma_{\mathrm{sim}}}{\sigma_{\mathrm{Obs}}}-1\right)^{2}+\left(\frac{\mu_{\mathrm{sim}}}{\mu_{\mathrm{Obs}}}-1\right)^{2}},
$$

with $r$ : simple correlation coefficient between observed and simulated values, $\sigma_{\mathrm{Obs}}$ : standard deviation of observed solid transport values, $\sigma_{\text {sim }}$ : standard deviation of simulated solid transport values, $\mu_{\mathrm{Obs}}$ : mean of observed solid transport values, $\mu_{\text {sim }}$ : mean of simulated solid transport values. The optimal value of the KGE factor is 1.

The PBAIS calibration of the model shows that the scaling factor (a) does not change while (b) is more sensitive, but remains close to the initial value. Table 12 shows the results of the PBIAS model calibration.

Table 12. Model calibration results at the four stations studied by percentage bias method (PBIAS).

\begin{tabular}{cccccc}
\hline Name of Basin & \multicolumn{2}{c}{$\begin{array}{c}\text { Scaling Parameters } \\
\text { after Calibration }\end{array}$} & \multicolumn{3}{c}{ Calibration Criteria } \\
& $\mathrm{A}$ & $\mathrm{B}$ & Bias & KGE & $\mathrm{r}$ \\
\hline Bouregreg & 11.799 & 0.548 & 0.00 & 0.48 & 0.58 \\
Grou & 11.799 & 0.535 & 0.00 & 0.11 & 0.26 \\
Korifla & 11.800 & 0.541 & 0.00 & 0.49 & 0.57 \\
Machraa & 11.799 & 0.502 & 0.00 & 0.65 & 0.70 \\
\hline
\end{tabular}

Calibration of the model by the KGE method shows that the scaling factors a and $b$ are very sensitive, with the terms being very far from the initial values, and are quite or widely and varyingly different from one basin to another. Table 13 shows the results of model calibration using the KGE method. 
Table 13. Model calibration results for the four stations studied by KGE.

\begin{tabular}{cccccc}
\hline Name of Basin & \multicolumn{2}{c}{$\begin{array}{c}\text { Scaling Parameters } \\
\text { after Calibration }\end{array}$} & \multicolumn{3}{c}{ Calibration Criteria } \\
& $\mathrm{A}$ & $\mathrm{b}$ & Bias & KGE & $\mathrm{r}$ \\
\hline Bouregreg & 0.039 & 0.807 & 0.024 & 0.601 & 0.603 \\
Grou & 11.799 & 0.546 & -0.236 & 0.149 & 0.272 \\
Korifla & 1.727 & 0.643 & -0.055 & 0.537 & 0.545 \\
Machraaf & 1.421 & 0.620 & -0.017 & 0.689 & 0.690 \\
\hline
\end{tabular}

\subsection{Comparison of Observations with MUSLE Model Results}

\subsubsection{Aguibat Zear Hydrological Station on the Bouregreg River}

During the two hydrological years studied, twenty-seven floods were recorded. The total solid volumes observed were 742,334 tons in 2016/2017 and 439,735 tons in 2017/2018. Table 14 summarizes the results from applying the model to the Aguibat Zear hydrological station.

Table 14. Results of the MUSLE model at Aguibat Zear on the Bouregreg and a comparison with observations.

\begin{tabular}{|c|c|c|c|c|c|c|c|}
\hline \multirow[t]{2}{*}{$\begin{array}{l}\text { Hydrologic } \\
\text { Year }\end{array}$} & \multirow[t]{2}{*}{$\begin{array}{c}\text { Observed Solid } \\
\text { Transport } \\
\text { (tons) }\end{array}$} & \multicolumn{3}{|c|}{$\begin{array}{l}\text { Solid Transport } \\
\text { (MUSLE) } \\
\text { (tons) }\end{array}$} & \multicolumn{3}{|c|}{$\begin{array}{c}\text { Difference } \\
\text { Observation-MUSLE } \\
(\%)\end{array}$} \\
\hline & & Uncalibrated & $\begin{array}{c}\text { Calibration } \\
\text { PBAIS }\end{array}$ & $\begin{array}{c}\text { Calibration } \\
\text { KGE }\end{array}$ & Uncalibrated & $\begin{array}{l}\text { Calibration } \\
\text { PBAIS }\end{array}$ & $\begin{array}{c}\text { Calibration } \\
\text { KGE }\end{array}$ \\
\hline $2016 / 2017$ & 742334 & 619023 & 487494 & 436922 & -17 & -34 & -41 \\
\hline $2017 / 2018$ & 439735 & 888011 & 694575 & 716809 & +102 & +58 & +63 \\
\hline
\end{tabular}

Examination of the results of the MUSLE model calibrated by the two approaches-PBAIS and KGE-shows that calibration by the PBAIS method better simulates solid transport. Figure 9 compares the simulated and observed solid transport. The latter events are less well simulated by MUSLE than the former.

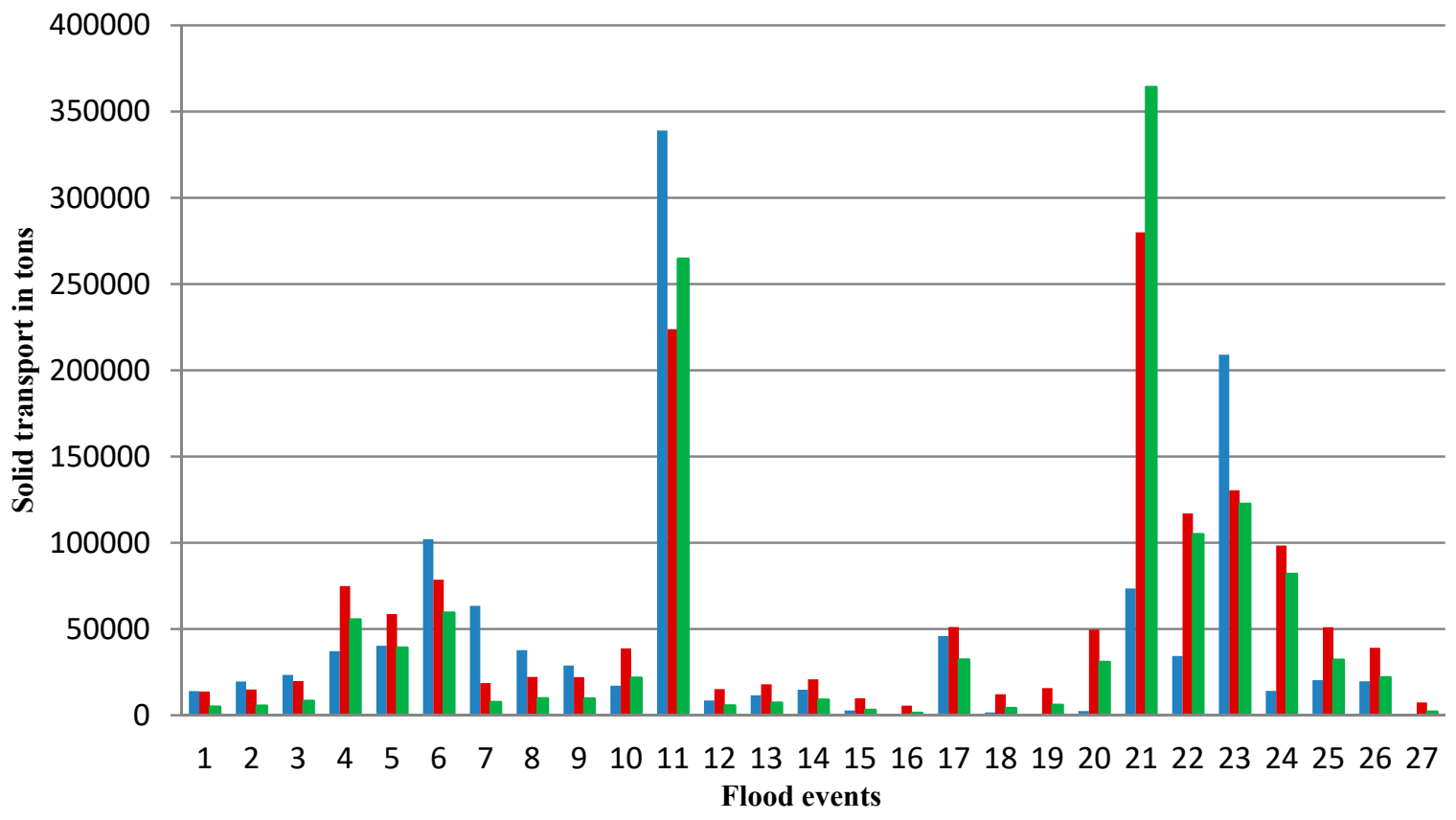

Figure 9. Comparison between MUSLE and observations at Aguibat Zear on the Bouregreg. 


\subsubsection{Ras Fathia Hydrological Station on the Grou River}

During the two hydrological years studied, twenty-one floods were recorded. The total observed solid volumes amount to 517,194 tons in 2016/2017 and 896,438 tons in 2017/2018. Table 15 summarizes the results of applying the model to the Ras Fathia hydrological station for the two versions of the model calibration.

Table 15. Results of the MUSLE model at Ras Fathia on the Grou and comparison with observations.

\begin{tabular}{|c|c|c|c|c|c|c|c|}
\hline \multirow[t]{2}{*}{$\begin{array}{l}\text { Hydrologic } \\
\text { Year }\end{array}$} & \multirow[t]{2}{*}{$\begin{array}{l}\text { Observed Solid } \\
\text { Transport } \\
\text { (tons) }\end{array}$} & \multicolumn{3}{|c|}{$\begin{array}{l}\text { Solid Transport } \\
\text { (MUSLE) } \\
\text { (tons) }\end{array}$} & \multicolumn{3}{|c|}{$\begin{array}{c}\text { Difference } \\
\text { Observation-MUSLE } \\
(\%)\end{array}$} \\
\hline & & Uncalibrated & $\begin{array}{c}\text { Calibration } \\
\text { PBAIS }\end{array}$ & $\begin{array}{c}\text { Calibration } \\
\text { KGE }\end{array}$ & Uncalibrated & $\begin{array}{c}\text { Calibration } \\
\text { PBAIS }\end{array}$ & $\begin{array}{c}\text { Calibration } \\
\text { KGE }\end{array}$ \\
\hline $2016 / 2017$ & 673551 & 875366 & 517194 & 649389 & +30 & -23 & -4 \\
\hline $2017 / 2018$ & 740083 & 1446831 & 896438 & 1098213 & +95 & +21 & +48 \\
\hline
\end{tabular}

Examination of the results of the MUSLE model calibrated by the two approaches PBAIS and KGE, shows that calibration by the PBAIS method better simulates solid transport. Figure 10 shows the comparison of simulated and observed solid transport. As for the Bouregreg, the events of the second year are less well represented by MUSLE.

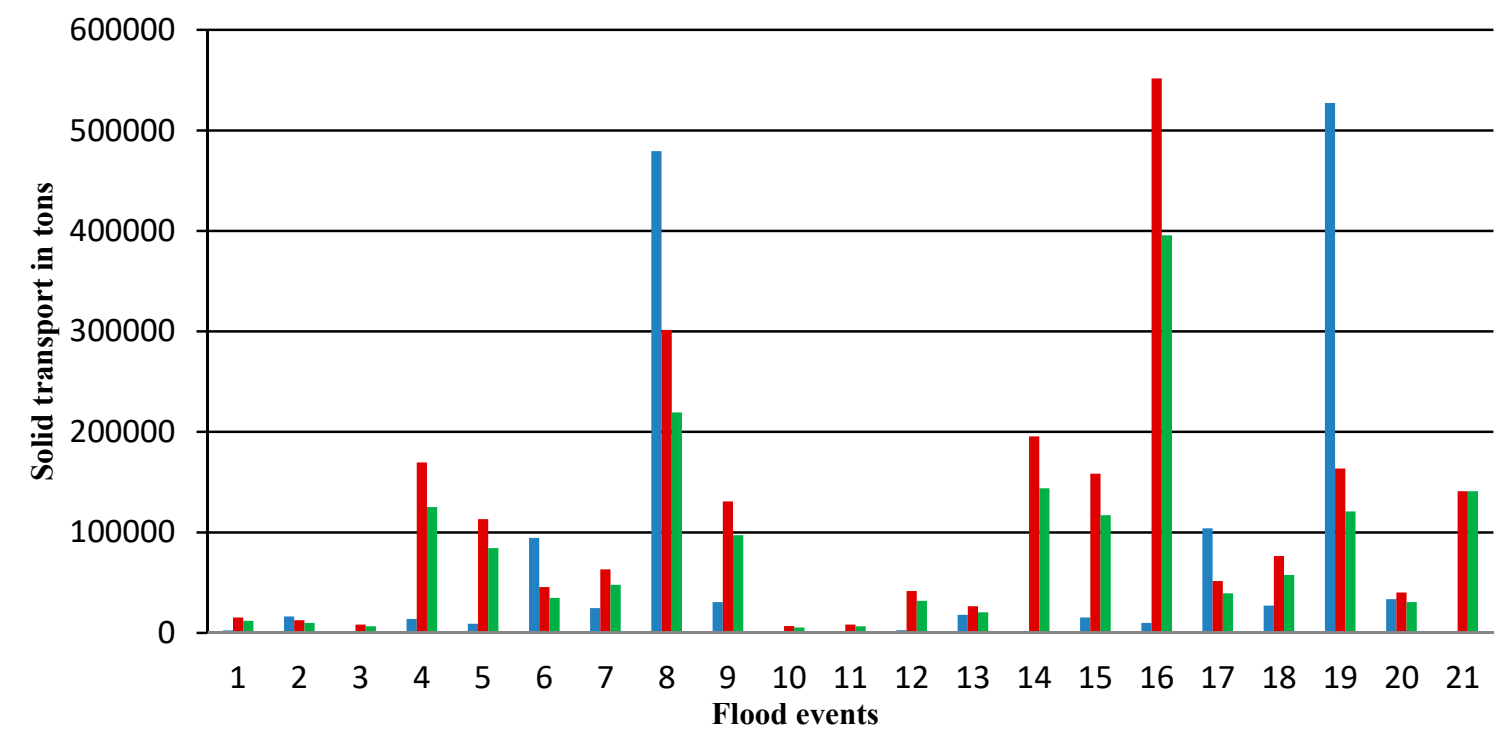

๑ Observed solid transport $\square$ Solid transport (MUSLE) $\quad$ Solid transport (MUSLE_Calibrated)

Figure 10. Comparison between MUSLE and observations at Ras Fathia on the Grou.

\subsubsection{Sidi Mohamed Cherif Hydrological Station on the Machraa River}

During the two hydrological years studied, twelve floods were recorded. The total solid volumes observed were 28,155 tons in 2016/2017 and 48,422 tons in 2017/2018. Table 16 summarizes the results of the application of the model to the hydrological station Sidi Mohamed Cherif. 
Table 16. Results of the MUSLE model at Sidi Mohamed Cherif on the Machraa and comparison with observations.

\begin{tabular}{|c|c|c|c|c|c|c|c|}
\hline \multirow[t]{2}{*}{$\begin{array}{c}\text { Hydrologic } \\
\text { Year }\end{array}$} & \multirow[t]{2}{*}{$\begin{array}{c}\text { Observed Solid } \\
\text { Transport } \\
\text { (tons) }\end{array}$} & \multicolumn{3}{|c|}{$\begin{array}{l}\text { Solid Transport } \\
\text { (MUSLE) } \\
\text { (tons) }\end{array}$} & \multicolumn{3}{|c|}{$\begin{array}{c}\text { Difference } \\
\text { Observation-MUSLE } \\
(\%)\end{array}$} \\
\hline & & Uncalibrated & $\begin{array}{c}\text { Calibration } \\
\text { PBAIS }\end{array}$ & $\begin{array}{c}\text { Calibration } \\
\text { KGE }\end{array}$ & Uncalibrated & $\begin{array}{c}\text { Calibration } \\
\text { PBAIS }\end{array}$ & $\begin{array}{c}\text { Calibration } \\
\text { KGE }\end{array}$ \\
\hline $2016 / 2017$ & 28,155 & 75,194 & 27,431 & 26,225 & +167 & -3 & -7 \\
\hline $2017 / 2018$ & 48,422 & 141,249 & 49,146 & 51,657 & +192 & +1 & +7 \\
\hline
\end{tabular}

Examination of the results of the MUSLE model calibrated by the two approaches-PBAIS and KGE-shows that calibration by the PBAIS method better simulates solid transport. Figure 11 shows the comparison of simulated and observed solid transport. Again, the MUSLE simulations are significantly too high for the events in the recording portion.

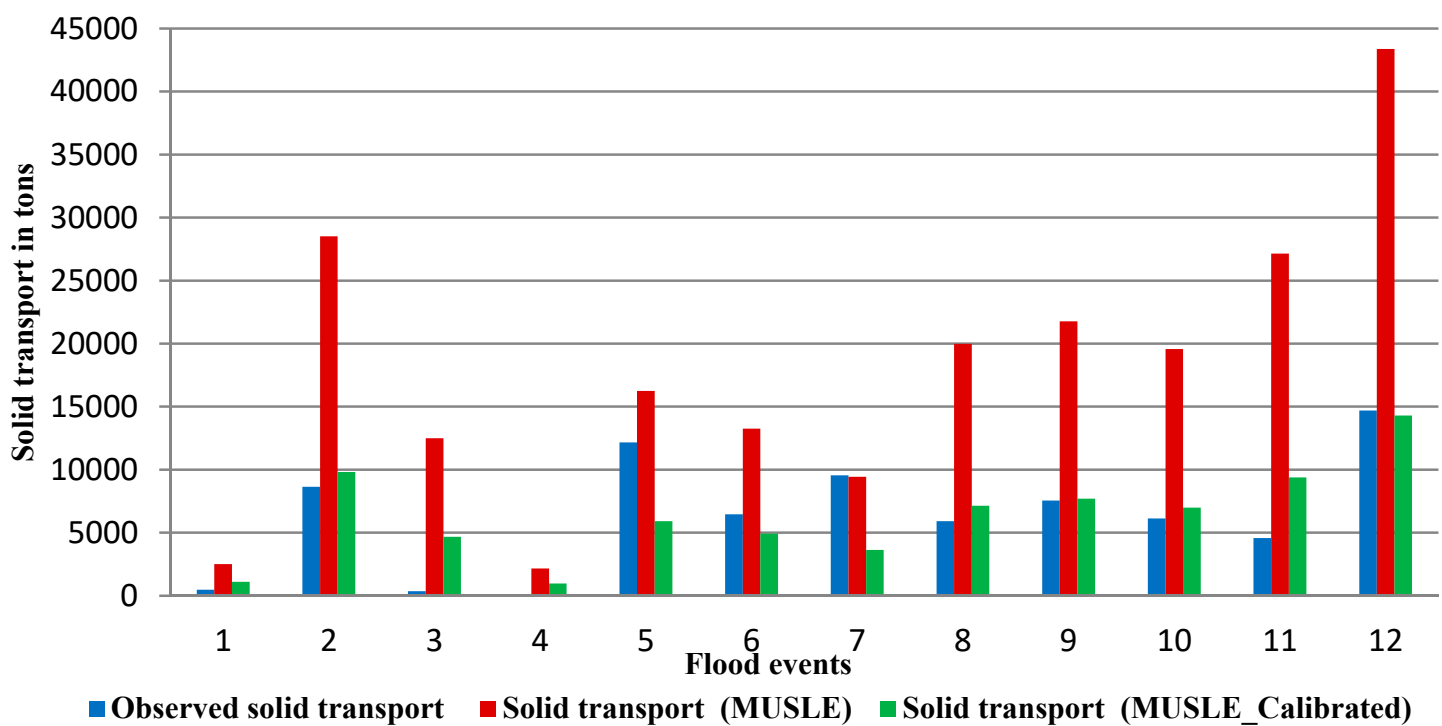

Figure 11. Comparison between MUSLE and observations at Sidi Mohamed Cherif on the Machraa.

\subsubsection{Ain Loudah Hydrological Station on the Korifla River}

During the two hydrological years studied, twenty-seven floods were recorded. The total solid volumes observed were 68,759 tons in 2016/2017 and 92,324 tons in 2017/2018. Table 17 summarizes the results of the application of the model to the Ain Loudah hydrological station.

Table 17. Results of the MUSLE model at Ain Loudah on the Korifla and comparison with observations.

\begin{tabular}{|c|c|c|c|c|c|c|c|}
\hline \multirow[t]{2}{*}{$\begin{array}{l}\text { Hydrologic } \\
\text { Year }\end{array}$} & \multirow[t]{2}{*}{$\begin{array}{l}\text { Observed Solid } \\
\text { Transport } \\
\text { (tons) }\end{array}$} & \multicolumn{3}{|c|}{$\begin{array}{l}\text { Solid Transport } \\
\text { (MUSLE) } \\
\text { (tons) }\end{array}$} & \multicolumn{3}{|c|}{$\begin{array}{c}\text { Difference } \\
\text { Observation-MUSLE } \\
(\%)\end{array}$} \\
\hline & & Uncalibrated & $\begin{array}{c}\text { Calibration } \\
\text { PBAIS }\end{array}$ & $\begin{array}{c}\text { Calibration } \\
\text { KGE }\end{array}$ & Uncalibrated & $\begin{array}{c}\text { Calibration } \\
\text { PBAIS }\end{array}$ & $\begin{array}{c}\text { Calibration } \\
\text { KGE }\end{array}$ \\
\hline $2016 / 2017$ & 68,759 & 41,083 & 28,881 & 27,739 & -40 & -58 & -60 \\
\hline $2017 / 2018$ & 92,324 & 191,859 & 132,202 & 142,138 & +108 & +43 & +54 \\
\hline
\end{tabular}

Examination of the results of the MUSLE model calibrated by the two approaches PBAIS and KGE, shows that calibration by the PBAIS method better simulates solid transports. Figure 12 shows the comparison of simulated and observed solid transports. Out of the four stations studied, it is on the Korifla at Ain Loudah that the simulations seem to be the most efficient. 


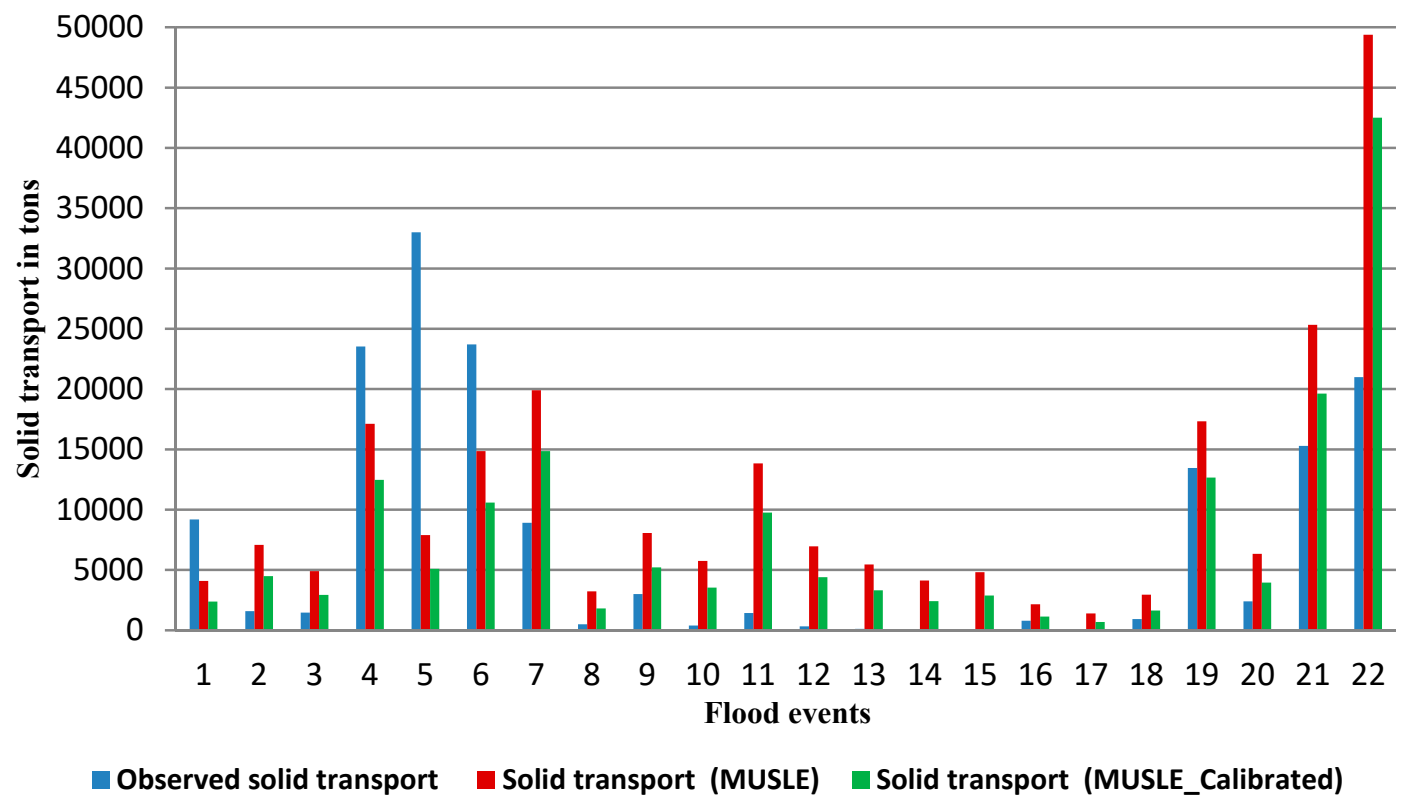

Figure 12. Comparison between MUSLE and observations at Ain Loudah on the Korifla.

From the deviations from observations at the four hydrological stations, it can be deduced that in general, the model calibrated by the PBAIS method gives better results than the model calibrated by the KGE method. Thus, from the observation we note that the differences varied between $-58 \%$ and $+58 \%$ for the model calibrated by PBAIS, between $-60 \%$ and $+63 \%$ for the model calibrated by the KGE method, and between $-40 \%$ and $+192 \%$ for the model not calibrated.

3.5. Comparison of Observations and Results of the MUSLE Model at the Four Hydrological Stations Upstream from the SMBA Dam, with Bathymetric Data

To validate the calibration method, the Nash and Sutcliffe NSE index was used to measure the performance of the model. According to Nash-Sutcliffe [56], NSE is defined as:

$$
\mathrm{NSE}=1-\frac{\sum_{i=1}^{n}\left(\mathrm{Y}_{\mathrm{i}}^{\mathrm{obs}}-\mathrm{Y}_{\mathrm{i}}^{\mathrm{Sim}}\right)^{2}}{\sum_{i=1}^{n}\left(\mathrm{Y}_{\mathrm{i}}^{\mathrm{obs}}-\mu_{\mathrm{Obs}}\right)^{2}}
$$

With NSE: Nash coefficient, $Y_{i}^{\text {obs }}$ : observed solid transport, $Y_{i}^{\text {sim }}$ : solid transport simulated by MUSLE, $\mu_{\mathrm{Obs}}$ : average of the observed solid transport values.

The NSE index varies from $-\infty$ to 1 , such that if NSE $=1$, then the modeled values match the observations perfectly, while a value above 0 shows a relationship between simulation and reality, and a value below 0 shows that there is no relationship between the two. In other words, the closer the efficiency is to 1 , the more the model is observed to be accurate.

Table 18 shows the different calculated values of the Nash-Sutcliffe index, which compares observations to the values calculated by the uncalibrated MUSLE model and observations to the values of the calibrated MUSLE model. 
Table 18. Nash-Sutcliffe index (NSE) at study stations.

\begin{tabular}{ccccc}
\hline Name of Basin & \multicolumn{2}{c}{$\begin{array}{c}\text { Scaling Parameters } \\
\text { after Calibration }\end{array}$} & \multicolumn{2}{c}{ Nash-Sutcliffe Index (NSE) } \\
& a & $\mathrm{B}$ & MUSLE & MUSLE calibrated \\
Bouregreg à Aguibat Zear & 11.799 & 0.548 & 0.38 & 0.46 \\
Grou à Ras Fathia & 11.799 & 0.535 & -0.07 & 0.02 \\
Korifla à Ain Loudah & 11.800 & 0.541 & -0.35 & 0.30 \\
Machraa à Sidi & 11.799 & 0.502 & -9.8 & 0.47 \\
Mohammed Cherif & & & & \\
\hline
\end{tabular}

In general, the uncalibrated MUSLE model has negative NSE values except for those in the Bouregreg basin, which shows that the model values are far from reality, whereas the NSE values of the calibrated model are positive, varying between 0.02 and 0.47 , which shows that the calibrated model is superior in reliably representing reality.

Though, for the continuity of the experiment we are continuing the calculation on the four basins in order to complete the comparisons with the volumes of sediment deduced from the bathymetric measurements carried out in the SMBA dam reservoir. For the calculation of the volume of suspended matter, an earthy density of $1.5 \mathrm{t} / \mathrm{m}^{3}$ is adopted [57]. The siltation of the dam is considered to be equal to $9.49 \times 10^{6} \mathrm{~m}^{3} /$ year. Table 19 summarizes the results of the calculations for all the hydrological stations.

Table 19. Summary table of observation results, application of the MUSLE, calibrated MUSLE_ model and bathymetry for the four sub-basins of the Bouregreg.

\begin{tabular}{|c|c|c|c|c|c|c|}
\hline \multirow[t]{2}{*}{ Name of Basin } & \multicolumn{3}{|c|}{ Solid Transport 2016/2017 } & \multicolumn{3}{|c|}{ Solid Transport $2017 / 2018$} \\
\hline & Observation & MUSLE & $\begin{array}{c}\text { MUSLE } \\
\text { calibrated }\end{array}$ & Observation & MUSLE & $\begin{array}{c}\text { MUSLE } \\
\text { calibrated }\end{array}$ \\
\hline Bouregreg & 742,334 & 619,023 & 487,494 & 439,735 & 888,011 & 694,575 \\
\hline Grou & 673,551 & 875,366 & 517,194 & 740,083 & $1,446,831$ & 896,438 \\
\hline Korifla & 68,759 & 41,083 & 28,881 & 92,324 & 191,859 & 132,202 \\
\hline Machraa & 28,155 & 75,194 & 27,431 & 48,422 & 141,249 & 49,146 \\
\hline Total (tons) & $1,512,799$ & $1,610,666$ & $1,061,000$ & $1,320,564$ & $2,667,950$ & $1,772,361$ \\
\hline Total $\left(10^{6} \mathrm{~m}^{3}\right)$ & 1.01 & 1.07 & 0.71 & 0.88 & 1.78 & 1.18 \\
\hline
\end{tabular}

Thus, the results listed in Tables 19 and 20 show that the calibrated model is closer to the measurement than the non-calibrated model, and that the observed values of sediment transport at the four stations, which vary between $1.01 \times 10^{6} \mathrm{~m}^{3}$ and $0.88 \times 10^{6} \mathrm{~m}^{3}$ for the two hydrological years 2016/2017 and 2017/2018 respectively, and remain largely lower than the quantity of sediments obtained by bathymetric measurements in the SMBA dam, which is approximately $9.49 \times 10^{6} \mathrm{~m}^{3}$.

Table 20. Comparison of observation results, application of the calibrated MUSLE, MUSLE_ model, and bathymetry for the four sub-basins of the Bouregreg during 2016/2017 and 2017/2018.

\begin{tabular}{ccccccc}
\hline $\begin{array}{c}\text { Hydrologic } \\
\text { Year }\end{array}$ & $\begin{array}{c}\text { Bathymetry } \\
\left(\mathbf{1 0}^{\mathbf{6}} \mathbf{m}^{\mathbf{3}}\right)\end{array}$ & $\begin{array}{c}\text { Difference } \\
\text { MUSLE/ } \\
\text { Observation }\end{array}$ & $\begin{array}{c}\text { Difference } \\
\text { MUSLE } \\
\text { Calibrated/ } \\
\text { Observation }\end{array}$ & $\begin{array}{c}\text { Difference } \\
\text { Observation/ } \\
\text { Bathymetry }\end{array}$ & $\begin{array}{c}\text { Difference } \\
\text { MUSLE/ } \\
\text { Bathymetry }\end{array}$ & $\begin{array}{c}\text { Difference } \\
\text { MUSLE } \\
\text { Calibrated/ } \\
\text { Bathymetry }\end{array}$ \\
\hline $2016 / 2017$ & 9.25 & $+5 \%$ & $-30 \%$ & $-89 \%$ & $-89 \%$ & $-93 \%$ \\
$2016 / 2018$ & $+102 \%$ & $+34 \%$ & $-91 \%$ & $-81 \%$ & $-88 \%$ \\
\hline
\end{tabular}

\section{Discussion and Conclusions}

The relationships between man, environment, and solid transport are well understood at the spatial scale of catchment areas, and modeling tools using satellite data are particularly suitable [58]. The results obtained from the application of the model (MUSLE), show that the soils of the Bouregreg catchment area are affected by several factors engendering erosion, i.e., steep slopes, low vegetation 
cover and soil erodibility. Thus, the processing of spatial remote sensing images to determine the biophysical characteristics of the watershed has made it possible to identify areas of high erodibility, low vegetation cover, and steep slopes, which can be used for potential development purposes.

The analysis of solid transports observed during two years at the four hydrological stations that control the main tributaries of the SMBA dam reservoir showed that the Bouregreg and the Grou generated 1,415,885 tons of suspended matter, i.e., 94\% and 956,929 tons of suspended matter, i.e., $73 \%$ of the total suspended matter generated by the four basins during the 2016/2017 and 2017/2018 hydrological years. Compared to bathymetry, the four sub-basins generate only $12 \%$ of the solid transport to the dam in the best case. Hence the relevance of concentrating anti-erosion actions on the dam banks and the intermediate basin which contribute to more than $88 \%$ of the solid transport. These actions will have to be carried out in areas of high erodibility and slope to ensure the effectiveness of the intervention.

On the other hand, examination of the figures for MUSLE and calibrated MUSLE values shows that the model in these two versions does not predict peaks in solid transport well. It overestimates low values and underestimates high solid transport values most of the time. Indeed, the deviations from observations range from $+5 \%$ for the dry year, to $+102 \%$ for the wet year for the non-calibrated model. These results are similar to several applications of the model in different areas around the world [40]. The deviations recorded for the calibrated model are significantly improved. They vary respectively between $-30 \%$ and $+34 \%$ [59]. Thus, the calibrated version of the model gives better results with less than $+55 \%$ error in sediment prediction [60]. These results are interesting on an interannual average, but do not allow the prediction of quantities transported to the stations during unit floods due to the very high dispersion of the relationship between observation and modeling, which results in average-to-low Nash index values. The large positive differences are due to the underestimation of solid transport peaks by the model. Indeed, the model involves the entire basin without concern for the spatial and temporal distribution of rainfall.

Although the model overestimates values relative to observations, comparison of the model to bathymetric data shows that the differences between mean siltation and model results range from $-89 \%$ to $-81 \%$ for the non-calibrated version of the model, and from $-93 \%$ to $-88 \%$ for the calibrated version. This underestimation of the inflows to the dam in relation to the mean silting is explained by the fact that the upstream basins do not control the whole SMBA dam basin and that the basins immediately surrounding the banks of the dam reservoir bring significant quantities of sediment to the dam, as assumed by the first results of Maleval [61] on the SMBA dam reservoir, and this is mainly after its elevation, for reasons that are perhaps not only related to the physics of the environment, but also perhaps to the evolution of agro-sylvo-pastoral practices in an environment undergoing rapid socio-economic change due to the proximity of the capital and the development of the "Grand Rabat" and new traffic routes $[62,63]$. The gaps between the observed solid transport and the silting rate, which are respectively $-89 \%$ and $-91 \%$, confirm this observation, which is also the situation observed by Hallouz et al. [64] on the Wadi Mina basin and the Sidi Mohamed Ben Aouda dam, of a size comparable to the Bouregreg in Western Algeria.

In order to improve the model's output, its scaling parameters should be reviewed and its sensitivity to different physical factors including basin size by adopting a distributed form of sub-basin modeling should be tested [65]. This approach requires a long series of observations thatare currently unavailable, but which are being acquired since the $\mathrm{ABHBC}$, which manages the water resource on the Bouregreg catchment area and the SMBA dam, has set up permanent concentration of suspended solids observation on the stations of the basin, and soon a long time series will be available to refine these first results. Michalec et al. [66] have pointed out the necessity to calibrate the MUSLE model with long time series of observations in order to reduce the uncertainty of simulated erosion provided, even if in some cases very good correlations have been obtained from a calibration with only 10 events like in Nigeria [30]. These measurements will allow a monitoring of the contribution of each sub-basin in order to better direct intervention measurements towards the most productive areas on the one 
hand, thus reducing the overall cost of the measures to reduce erosion, and to improve modeling and subsequent solid transport forecasting on the other hand.

Eventually, the results of the MUSLE model confirm the relevance of its application in watershed management studies once calibrated, since it integrates all forms of erosion observed at the watershed scale, coupled with hydrological data, which greatly improves accuracy compared to USLE [67] and to RUSLE [68]. Indeed, the average specific degradation at the level of the Bouregreg basin alone at the Aguibat Zear station is of the order of $13.81 \mathrm{t} / \mathrm{ha}$ /year according to Moussebbih et al. [69] when calculated by the RUSLE method, whereas those of calibrated MUSLE and observation are of the order of 1.6 $\mathrm{t} / \mathrm{ha}$ /year. The studies carried out on the wadi Mina basin in Algeria, a basin similar to the Bouregreg basin [64], confirm this finding with deviations of the RUSLE model results from the measurement of suspended solids concentrations, which can reach 79\%. In Spain, Ramos-Diez et al. [70] have used the USLE formula to assess the amount of sediment inputs to 25 very small check dams used in an important restoration project over a $9 \mathrm{~km}^{2}$ area in the north of Spain, showing interesting but still mitigated results and concluding that the size and shape of the dams had an impact on the quality of the USLE assessment.

Kronvang et al. [71] showed that bank erosion was the dominant sediment source (90-94\%) in the River Odense catchment in Denmark during three study years. They add that in-channel and overbank sediment sinks and storage dominated the sediment budget, as 79-94\% of the sediment input from all sources was not exported from the catchment during the three study years. This is in accordance with our results, as the regular bathymetric survey to monitor the silting up rate of the dam have shown that half of the sediment input to the reservoir comes from the dam banks. Our results are very important for the forthcoming works for erosion mitigation on the Bouregreg catchment; they will enable more efficient orientation of the soil conservation and restoration works that may be carried out in the future, with priority being given to the environment close to the dam, in order to preserve the water capacity of the SMBA dam reservoir while optimizing the financial resources mobilized. Palazon and Navas [72] have shown the same interest to monitor the sediment sources draining to a large reservoir in the Esera River, Ebro basin in Spain. The small basin size $\left(1500 \mathrm{~km}^{2}\right)$ allowed them to use the SWAT model as an alternative to MUSLE with two gauging stations, each one being covered by different types of soil. This might make it possible to implement the SWAT model on the Bouregreg basin, when the ABHBC will have started the monitoring of sediment transport at all the stations of the basin.

To conclude, it should be pointed out that in the context of climate change, which predicts, in Morocco, an increase in temperatures and a drop in rainfall [73-75], the projections of erosion and sediment transport evolution that are possible from climate model outputs, and which are based on USLE or SWAT type approximation models [76], will need observed data to calibrate and validate their results.

Author Contributions: Conceptualization, M.A.E. and G.M.; methodology, M.A.E.; software, M.A.E.; validation, G.M., I.K. and A.Z.; formal analysis, M.A.E.; investigation, M.A.E.; resources, A.Z.; data curation, A.Z.; writing-original draft preparation, M.A.E. and G.M.; writing-review and editing, M.A.E.; visualization, M.A.E.; supervision, G.M., I.K. and A.Z.; project administration, G.M., I.K. and A.Z. All authors have read and agreed to the published version of the manuscript.

Funding: This research received no external funding.

Acknowledgments: Thanks to ABHBC for the hydrological and rainfall data.

Conflicts of Interest: The authors declare no conflict of interest.

\section{References}

1. Mahe, G.; Emran, A.; Brou, Y.T.; Tra Bi, A.Z. Analyse statistique de l'évolution de la couverture végétale à partir d'images MODIS et NOAA sur le bassin versant du Bouregreg (Maroc). Géo Obs. 2012, 20, $33-44$. 
2. Laouina, A.; Aderghal, M.; Al Karkouri, J.; Antari, M.; Chaker, M.; Laghazi, Y.; Machmachi, I.; Machouri, N.; Nafaa, R.; Naïmi, K. The efforts for cork oak forest management and their effects on soil conservation. For. Syst. 2010, 19, 263-277. [CrossRef]

3. Schmidt, S.; Alewell, C.; Meusburger, K. Monthly RUSLE soil erosion risk of Swiss grasslands. J. Maps 2019, 15, 247-256. [CrossRef]

4. Yahiaoui, S.; Zerouali, A. Etude de l'évolution de l'occupation du sol sur deux grands bassins d'Algérie et du Maroc, et relation avec la sédimentation dans les barrages. In Considering Hydrological Change in Reservoir Planning and Management; IAHS Publ 362; Schumann, A., Belyaev, V.B., Gargouri, E., Kucera, G., Mahe, G., Eds.; IAHS Press: Wallingford, UK, 2013; pp. 115-124.

5. Khomsi, K.; Mahe, G.; Sinan, M.; Snoussi, M. Hydro-climatic variability in two Moroccan watersheds: A comparative analysis of temperature, rain and flow regimes. In Climate and Land Surface Changes in Hydrology; IAHS Publ. 359; Boegh, E., Blyth, E., Hannah, D.M., Hisdal, H., Kunstmann, H., Su, B., Yilmaz, K.K., Eds.; IAHS Press: Wallingford, UK, 2013; pp. 183-190.

6. Khomsi, K.; Mahe, G.; Tramblay, Y.; Sinan, M.; Snoussi, M. Regional impacts of global change: Seasonal trends in extreme rainfall, runoff and temperature in two contrasted regions of Morocco. Nat. Hazards Earth Syst. Sci. 2016, 16, 1079-1090. [CrossRef]

7. Mahe, G.; Emran, A.; Brou, Y.T.; Tra Bi, A.Z. Impact de la variabilité climatique sur l'état de surface du bassin versant du Bouregreg (Maroc). Eur. J. Sci. Res. 2012, 84, 417-425.

8. ABV. Plan National d'Aménagement des Bassins Versant; Haut-Commissariat aux Eaux et Forêts et à la Lutte Contre la Désertification: Rabat, Morocco, 1996.

9. Wischmeier, W.H.; Smith, D.D. Predicting Rainfall-Erosion Losses from Cropland East of the Rocky Mountains: Guide for Selection of Practices for Soil and Water Conservation; US Department of Agriculture: Washington, DC, USA, 1965.

10. Williams, J.R. Sediment-Yield Prediction with Universal Equation Using Runoff Energy Factor; ARS-S. Southern Region, Agricultural Research Service, US Department of Agriculture: Washington, DC, USA, 1975; Volume 40, p. 244.

11. El Bahi, S.; El Wartiti, M.; Yassin, M.; Calle, A.; Casanova, J.L. Applying revised universal loss equation model to forest lands in Central Plateau of Morocco. Rev. Teledetección 2005, 23, 89-97.

12. Chadli, K. Estimation of soil loss using RUSLE model for Sebou watershed (Morocco). Model. Earth Syst. Environ. 2016, 2, 51. [CrossRef]

13. Elaloui, A.; Marrakchi, C.; Fekri, A.; Maimouni, S.; Aradi, M. USLE-based assessment of soil erosion by water in the watershed upstream Tessaoute (Central High Atlas, Morocco). Modeling Earth Syst. Environ. 2017, 3, 873-885. [CrossRef]

14. Hara, F.; Achab, M.; Emran, A.; Mahe, G.; Fhel, B.E. Estimate the Risk of Soil Erosion Using USLE through the Development of an Open Source Desktop Application: DUSLE (Desktop Universal Soil Loss Equation). In Proceedings of the 3rd International Conference on African Large River Basin Hydrology, Alger, Algeria, May 2018; Available online: https://hal.archives-ouvertes.fr/hal-02397686/ (accessed on 17 June 2020).

15. Boufala, M.; El Hmaidf, A.; Chadli, K.; Essahlaoui, A.; El Ouali, A.; Lahjouj, A. Assessment of the Risk of Soil Erosion Using RUSLE Method and SWAT Model at the M'dez Watershed, Middle Atlas, Morocco. In Proceedings of the E3S Web Conf., The Seventh International Congress "Water, Waste and Environment" (EDE7-2019), Salé, Morocco, 20-22 November 2019; Volume 150. [CrossRef]

16. Toumi, S.; Meddi, M.; Mahe, G.; Brou, Y.T. Cartographie de l'érosion dans le bassin versant de l'Oued Mina en Algérie par télédétection et SIG. Hydrol. Sci. J. 2013, 58, 1-17. [CrossRef]

17. Mihi, A.; Benarfa, N.; Arar, A. Assessing and mapping water erosion-prone areas in northeastern Algeria using analytic hierarchy process, USLE/RUSLE equation, GIS, and remote sensing. Appl. Geomat. 2019. [CrossRef]

18. Gaubi, I.; Chaabani, A.; Ben Mammou, A.; Hamza, M.H. A GIS-based soil erosion prediction using the Revised Universal Soil Loss Equation (RUSLE) (Lebna watershed, Cap Bon, Tunisia). Nat. Hazards 2017, 86, 219-239. [CrossRef]

19. Toubal, A.K.; Achite, M.; Ouillon, S.; Dehni, A. Soil erodibility mapping using the RUSLE model to prioritize erosion control in the Wadi Sahouat basin. North-West Alger. Environ. Monit. Assess. 2018, 190, 4. [CrossRef] [PubMed] 
20. El Aroussi, O.; Mesrar, L.; El Garouani, A.; Lahrach, A.; Beaabidaate, L.; Akdi, B.; Jabrane, R. Predicting the potential annual soil loss using the revised universal soil loss equation (RUSLE) in the oued El Malleh catchment (Prerif, Morocco). Present. Environ. Sustain. Dev. 2011, 5, 5-16.

21. Lamyaa, K.; M’bark, A.; Brahim, I.; Hicham, A.; Soraya, M. Mapping Soil Erosion Risk Using RUSLE, GIS, Remote Sensing Methods: A Case of Mountainous Sub-watershed, Ifni Lake and High Valley of Tifnoute (High Moroccan Atlas). J. Geogr. Environ. Earth Sci. Int. 2018, 14, 1-11. [CrossRef]

22. Bagarello, V.; Ferro, V.; Giordano, G.; Mannocchi, F.; Todisco, F.; Vergni, L. Statistical check of USLE-M and USLE-MM to predict bare plot soil loss in two Italian environments. Land Degrad. Dev. 2018, 29, 2614-2628. [CrossRef]

23. Wischmeier, W.H.; Smith, D.D. Predicting Rainfall Erosion Losses: A Guide to Conservation Planning; Department of Agriculture, Science and Education Administration: Washington, DC, USA, 1978.

24. Renard, K.G. Predicting Soil Erosion by Water: A Guide to Conservation Planning with the Revised Universal Soil Loss Equation (RUSLE); United States Government Printing: Washington, DC, USA, 1997.

25. Kinnell, P.I.A. Why the Universal Soil Loss Equation and the Revised Version of It Do Not Predict Event Erosion Well. Hydrol. Process. 2005, 19, 851-854. [CrossRef]

26. Haan, C.T.; Barfield, B.J.; Hayes, J.C. Design Hydrology and Sedimentology for Small Catchments. J. Hydrol. -Amst. 1963, 176, 296-297.

27. Novotny, V. Water Quality: Prevention, Identification and Management of Diffuse Pollution; Van Nostrand-Reinhold Publishers: New York, NY, USA, 1994; ISBN 978-0442005597.

28. Alewell, C.; Borrelli, P.; Meusburger, K.; Panagos, P. Using the USLE: Chances, challenges and limitations of soil erosion modelling. Int. Soil Water Conserv. Res. 2019, 7, 203-225. [CrossRef]

29. Odongo, V.O.; Onyando, J.O.; Mutua, B.M.; van Oel, P.R.; Becht, R. Sensitivity analysis and calibration of the Modified Universal Soil Loss Equation (MUSLE) for the upper Malewa Catchment, Kenya. Int. J. Sediment Res. 2013, 28, 368-383. [CrossRef]

30. Adegede, A.P.; Mbajiorgu, C.C. Event-based sediment yield modeling for small watersheds using MUSLE in north-central Nigeria. Agric. Eng. Int.: CIGR J. 2019, 21, 7-17.

31. Yassin, M.; Pépin, Y.; El Bahi, S.; Zante, P. Evaluation de l'érosion au micro-bassin de Sidi Sbaa: Application du modèle MUSLE. Ann. Rech. For. Maroc 2013, 42, 171-181.

32. Samaras, A.G.; Koutitas, C.G. Modeling the impact of climate change on sediment transport and morphology in coupled watershed-coast systems: A case study using an integrated approach. Int. J. Sediment Res. 2014, 29, 304-315. [CrossRef]

33. Fang, H. Impact of land use changes on catchment soil erosion and sediment yield in the northeastern China: A panel data model application. Int. J. Sediment Res. 2020. [CrossRef]

34. Djoukbala, O.; Hasbaia, M.; Benselama, O.; Mazour, M. Comparison of the erosion prediction models from USLE, MUSLE and RUSLE in a Mediterranean watershed, case of Wadi Gazouana (N-W of Algeria). Modeling Earth Syst. Environ. 2018. [CrossRef]

35. Mahe, G.; Benabdelfadel, H.; Dieulin, C.; Elbaraka, M.; Ezzaouini, M.; Khomsi, K.; Rouche, N.; Sinan, M.; Snoussi, M.; Tra Bi, A.; et al. Evolution des débits liquides et solides du Bouregreg. In Gestion Durable des Terres. Proceedings de la Réunion Multi-Acteurs Sur le Bassin du Bouregreg. CERGéo, Faculté des Lettres et Sciences Humaines, Université Mohammed V-Agdal, Rabat, 28 mai 2013; Laouina, A., Mahe, G., Eds.; Edité par ARGDT: Rabat, Morocco, 2014; pp. 21-36, ISBN 978-9954-33-482-9.

36. Khali Issa, L.; Ben Hamman Lech-Hab, K.; Raissouni, A.; El Arrim, A. Cartographie quantitative du risque d'érosion des sols par approche SIG/USLE au niveau du bassin versant Kalaya (Maroc Nord Occidental). J. Mater. Environ. Sci. 2016, 7, 2778-2795.

37. El Jazouli, A.; Barakat, A.; Ghafiri, A.; El Moutaki, S.; Ettaqy, A.; Khellouk, R. Soil erosion modeled with USLE, GIS, and remote sensing: A case study of Ikkour watershed in Middle Atlas (Morocco). Geosci. Lett. 2017, 4, 1. [CrossRef]

38. Sabri, E. Impact des Processus Erosifs sur les Ressources Naturelles des Bassins Hydrographiques et sur L'état D'envasement des Retenues des Barrages: Application au Bassin Versant de L'oued El Abid en Amont du Barrage de Bin El Ouidane- Maroc. Ph.D. Thesis, Univ. Cadi Ayyad, Marrakech, Morocco, 2018.

39. Sadeghi, S.H.R.; Gholami, L.; Khaledi Darvishan, A.; Saeidi, P. A review of the application of the MUSLE model worldwide. Hydrol. Sci. J. 2014, 59, 365-375. [CrossRef] 
40. Aboulabbes, O. Infiltration Characteristics on a Small Watershed. Master's Thesis, Utah State University, Logan Utah, UT, USA, 1984.

41. El Gaatib, R.; Erraji, A.; Larabi, A. Impact des processus érosifs sur les ressources naturelles des bassins hydrographiques et sur l'état d'envasement des retenues de barrages: Application au Bassin Versant de l'Oued Beht en amont du barrage El Kansra, (Maroc). Géo Obs. 2014, 21, 4.

42. Jamagne, M. Bases et Techniques d'une Cartographie des Sols'; Institut National de la Recherche Agronomique: Paris, France, 1967.

43. Stone, R.P.; Hilborn, D. Universal Soil Loss Equation, USLE; Factsheet; Government of Ontario, Ministry of Agriculture, Food and Rural Affairs: Canada, 2000. Available online: http://www.omafra.gov.on.ca/english/ engineer/facts/12-051.htm (accessed on 17 June 2020).

44. Pribyl, D.W. A critical review of the conventional SOC to SOM conversion factor. Geoderma 2010, 156, 75-83. [CrossRef]

45. Van Bemmelen, J.M. “Über die Bestimmung des Wassers, des Humus, des Schwefels, der in den colloïdalen Silikaten gebundenen Kieselsäure, des Mangansuswim Ackerboden". Die LandwirthschaftlichenVers.-Stn. 1890, 37, 279-290.

46. Wolff, E. Entwurf zur boden analyse. Z. Anal. Chem. 1864, 3, 85-115. [CrossRef]

47. Sprengel, C. Ueber Pflanzenhumus, Humussaüre und humussaure Salze. Arch. für die Gesammte 1826, 8, 145-220. [CrossRef]

48. Tra Bi, Z.A.; Emran, A.; Brou, Y.T.; Mahé, G. Cartographie par arbre de décision de la dynamique de l'occupation du sol du bassin versant du Bouregreg, en région semi-aride au centre Nord-Ouest du Maroc, Abidjan, Côte d'Ivoire. Rev. Sci. Int. Géomatique 2014, 1, 43-54.

49. Sadiki, A.; Bouhlassa, S.; Auajjar, J. Utilisation d'un SIG pour l'évaluation et la cartographie des risques d'érosion par utilisation d'un SIG pour l'évaluation et la cartographie des risques d'érosion par l'équation universelle des pertes en sol dans le Rif oriental (Maroc). Bull. de l'Inst. Sci. 2004, 26, 69-79.

50. Goussot, E.; Brou, Y.T.; Laouina, A.; Chaker, M.; Emran, A.; Machouri, N.; Mahe, G.; Sfa, M.; Tra Bi, A. Land covers dynamic and agricultural statistics on the Bouregreg watershed in Morocco. Eur. J. Sci. Res. 2014, 126, 191-205.

51. Tra Bi, A.Z.; Brou, T.; Emran, A.; Mahe, G. Remote sensing and GIS analysis of the dynamic of vegetation in climate variability context on the Bouregreg watershed. In Climate and Land Surface Changes in Hydrology; IAHS Publ. 359; Boegh, E., Blyth, D.M., Hannah, H., Hisdal, H., Kunstmann, B., Su, K.K., Yilmaz, Eds.; IAHS Press: Wallingford, UK, 2013; pp. 403-410.

52. El Hadraoui, Y. Étude Diachronique de L'occupation du sol et de Modélisation des Processus Erosifs du Bassin Versant du Bouregreg (Maroc) à Partir des Données de L'observation de la Terre; Mémoire d'ingénieur du CNAM, Spécialité Géomètre et Topographe: Le Mans, France, 2013; Available online: https://dumas.ccsd.cnrs.fr/ dumas-00920465 (accessed on 17 June 2020).

53. Lahlou, A. La Dégradation Spécifique des Bassins Versants et son Impact sur L'envasement des Barrages; IAHS Publ. 137; IAHS Press: Wallingford, UK, 1982; pp. 163-169. Available online: https://pdfs.semanticscholar.org/ cddc/4f4b21f52e34043e1b0547d00d0e9dd389b9.pdf (accessed on 17 June 2020).

54. Gupta, H.V.; Sorooshian, S.; Yapo, P.O. Status of automatic calibration for hydrologic models: Comparison with multilevel expert calibration. J. Hydrol. Eng. 1999, 4, 135-143. [CrossRef]

55. Gupta, H.V.; Kling, H.; Yilmaz, K.K.; Martinez, G.F. Decomposition of the mean squared error and NSE performance criteria: Implications for improving hydrological modelling. J. Hydrol. 2009, 377, 80-91. [CrossRef]

56. Nash, J.E.; Sutcliffe, J.V. River flow forecasting through conceptual models part I-A discussion of principles. J. Hydrol. 1970, 10, 282-290. [CrossRef]

57. Lahlou, A. Etude du transport solide à la station Dar Es Soltane sur l'oued Bouregreg; Rapport de travaux du service GDE; Gestion des eaux, Ministère des travaux publics et des communications, Direction de l'hydraulique: Rabat, Morocco, 1971.

58. Mahe, G.; Aksoy, H.; Brou, Y.T.; Meddi, M.; Roose, E. Relationships among man, environment and sediment transport: A spatial approach. Rev. Sci. Eau 2013, 26, 235-244. [CrossRef]

59. De Vente, J.; Verduyn, R.; Verstraeten, G.; Vanmaercke, M.; Poesen, J. Factors controlling sediment yield at the catchment scale in NW Mediterranean geoecosystems. J. Soils Sediments 2011, 11, 690-707. [CrossRef] 
60. Moriasi, D.N.; Arnold, J.G.; Van Liew, M.W.; Bingner, R.L.; Harmel, R.D.; Veith, T.L. Model evaluation guidelines for systematic quantification of accuracy in watershed simulations. Transactions of the ASABE. Am. Soc. Agric. Biol. Eng. 2007, 50, 885-900.

61. Maleval, V. Premiers résultats des mesures d'érosion ravinaire sur les versants lacustres du barrage Sidi Mohamed ben Abdellah (Maroc) et perspectives de recherche. In Gestion Durable des Terres. Proceedings de la réunion multi-acteurs sur le bassin du Bouregreg. CERGéo, Faculté des Lettres et Sciences Humaines, Université Mohammed V-Agdal, Rabat, 28 mai 2013; Laouina, A., Mahe, G., Eds.; Edité par ARGDT: Rabat, Morocco, 2014; pp. 53-62, ISBN 978-9954-33-482-9.

62. Laouina, A.; Chaker, A.; Aderghal, M.; Machouri, N.; Al Karkouri, J. Echelles d'évaluation de la dynamique des terres et de leur gestion, du territoire social au bassin-versant expérimental. In Gestion Durable des Terres. Proceedings de la réunion multi-acteurs sur le bassin du Bouregreg. CERGéo, Faculté des Lettres et Sciences Humaines, Université Mohammed V-Agdal, Rabat, 28 mai 2013; Laouina, A., Mahe, G., Eds.; Edité par ARGDT: Rabat, Morocco, 2014; pp. 119-146, ISBN 978-9954-33-482-9.

63. Chaker, M.; Laouina, A.; El Marbouh, M. Changement agropastoral et dégradation des terres dans le plateau Sehoul. In Gestion Durable des Terres. Proceedings de la Réunion Multi-Acteurs sur le Bassin du Bouregreg. CERGéo, Faculté des Lettres et Sciences Humaines, Université Mohammed V-Agdal, Rabat, 28 mai 2013; Laouina, A., Mahe, G., Eds.; Edité par ARGDT: Rabat, Morocco, 2014; pp. 85-102, ISBN 978-9954-33-482-9.

64. Hallouz, F.; Mahé, G.; Toumi, S.; Rahmani, S.E.A. Erosion, suspended sediment transport and sedimentation on the Wadi Mina at the Sidi M'Hamed Ben Aouda Dam, Algeria. Water 2018, 10, 895. [CrossRef]

65. Gwapedza, D.; Hughes, D.A.; Slaughter, A.R. Spatial scale dependency issues in the application of the Modified Universal Soil Loss Equation (MUSLE). Hydrol. Sci. J. 2018, 63, 1890-1900. [CrossRef]

66. Michalec, B.; Walega, A.; Cupak, A.; Strutyński, M. Verification of the musle to determine the amount of suspended sediment. Carpathian J. Earth Environ. Sci. 2017, 12, 235-244.

67. Iroumé, A.; Carey, P.; Bronstert, A.; Huber, A.; Palacios, H. GIS application of USLE and MUSLE to estimate erosion and suspended sediment load in experimental catchments, Valdivia, Chile. Aplicación SIG de USLE y MUSLE para Estimar la Erosión y el Transporte de Sedimentos en Suspensión en Cuencasexperimentales 2011, 34 , 119-128.

68. Arekhi, S.; Shabani, A.; Alavipanah, S.K. Evaluation of integrated KW-GIUH and MUSLE models to predict sediment yield using geographic information system (GIS) (Case study: Kengir watershed, Iran). Afr. J. Agric. Res. 2011, 6, 4185-4198.

69. Moussebbih, A.; Souissi, M.; Larabi, A.; Faouzi, M. Modeling and mapping of the water erosion risk using Gis/Rusle approach in the Bouregreg river watershed. Int. J. Mech. Prod. Eng. Res. Dev. 2019, 9, 1605-1618. [CrossRef]

70. Ramos-Diez, I.; Navarro-Hevia, J.; San Martín, R.; Díaz-Gutiérrez, V.; Mongil-Manso, J. Evaluating methods to quantify sediment volumes trapped behind check dams, Saldaña badlands (Spain). Int. J. Sediment Res. 2016, 28, 2446-2456. [CrossRef]

71. Kronvang, B.; Andersen, H.E.; Larsen, S.E.; Audet, J. Importance of bank erosion for sediment input, storage and export at the catchment scale. J. Soils Sediments 2013, 13, 230-241. [CrossRef]

72. Palazón, L.; Navas, A. Modeling sediment sources and yields in a Pyrenean catchment draining to a large reservoir (Ésera River, Ebro Basin). J. Soils Sediments 2014, 14, 1612-1625. [CrossRef]

73. Driouech, F.; Mahé, G.; Déqué, M.; Dieulin, C.; El Heirech, T.; Milano, M.; Benabdelfadel, H.; Rouché, N. Evaluation d'impacts potentiels de changements climatiques sur l'hydrologie du bassin versant de la Moulouya au Maroc. In Global Change: Facing Risks and Threats to Water Resources. Proceedings of the Sixth World FRIEND Conference, Fez, Morocco, October 2010; IAHS Publ. 340; IAHS Press: Wallingford, UK, 2010; pp. 561-567. Available online: https://horizon.documentation.ird.fr/exl-doc/pleins_textes/divers15-08/ 010055009.pdf (accessed on 17 June 2020).

74. Filahi, S.; Tramblay, Y.; Mouhir, L.; Diaconescu, E.P. Projected changes in temperature and precipitation indices in Morocco from high-resolution regional climate models. Int. J. Climatol. 2017, 37, 4846-4863. [CrossRef] 
75. Tramblay, Y.; Jarlan, L.; Hanich, L.; Somot, S. Future scenarios of surface water resources availability in North African dams. Water Resour. Manag. 2018, 32, 1291-1306. [CrossRef]

76. Raclot, D.; Naimi, M.; Chikhaoui, M.; Nunez, J.P.; Huard, F.; Herivaux, C.; Sabir, M.; Pepin, Y. Distinct and combined impacts of climate and land use scenarios on water availability and sediment loads for a water supply reservoir in northern Morocco. Int. J. Soil Conserv. 2020. [CrossRef]

(C) 2020 by the authors. Licensee MDPI, Basel, Switzerland. This article is an open access article distributed under the terms and conditions of the Creative Commons Attribution (CC BY) license (http://creativecommons.org/licenses/by/4.0/). 